\title{
External pressures on accounting study programs: An institutional approach of stakeholder expectations
}

\author{
Cristina Circa ${ }^{\mathrm{a}}$, Alina Almășan ${ }^{1, \mathrm{a}}$ and Adina Popa ${ }^{\mathrm{b}}$ \\ ${ }^{\text {a }}$ West University of Timișoara, Romania \\ ${ }^{\mathrm{b}}$ University of Skövde, Sweden
}

\begin{abstract}
Research Question: What are the requirements and expectations of each class of external stakeholders? Is there any convergence between the identified expectations?

Motivation: There is a large variety of stakeholder expectations that universities are confronted with in their permanent search for social legitimacy, acknowledgement and survival. In the case of accounting study programs, their strong relationships with practitioners and professional associations, as emphasized in previous research in accounting education in Central and Eastern European (CEE) countries, add to the expectations that need to be met.
\end{abstract}

Idea: This paper explores external stakeholder expectations of accounting study programs provided by Romanian universities, in order to identify the elements to which these expectations converge.

Data: Data was collected only from public documents (laws and regulations, reports, studies, press releases, websites of relevant bodies etc.).

Tools: A review of relevant public documents has been performed.

Findings: As expected, all stakeholders require quality. Still, they ascribe different meanings to quality, evaluate quality in different manners, and hence exert various pressures. More, we observed that all types of isomorphism: coercive, mimetic, normative, as well as competitive are involved in assuring quality and meeting expectations.

Contribution: The study contributes to literature with a complex approach, employing stakeholder and institutional theory, in the context of the extensive environment of higher education. In terms of practice, by taking stock of stakeholder requirements and expectations, the study calls the attention of decision makers to stakeholder pressures and the need to adjust accounting study programs accordingly.

${ }^{1}$ Corresponding author: West University of Timișoara, Faculty of Economics and Business Administration, 16 J.H. Pestalozzi, 300115 Timișoara, Romania, email addresses: alina.almasan@e-uvt.ro. 
Keywords: institutional theory, stakeholders, expectations, higher education, accounting study programs

JEL Codes: 123, M40

\section{Introduction}

In permanent search for social legitimacy, acknowledgement and survival, universities have gone through major transformations during the last decades. Social, economic and political changes impact on the operation of universities, leading them to reconsider their strategic role in society. In this context, the relationship between universities and their external stakeholders gains in importance. The literature provides evidence that fields that are constantly reformed require a careful analysis of their stakeholders (Bryson, 2004). As regards universities, since they face a highly complex stakeholder environment, stakeholder analysis and management are more than pertinent (Chapleo \& Simms, 2010). Stakeholder identification and classification are essential to universities, as every category needs a different strategy in its approach (Avci et al., 2015).

The institutional theory has become a popular instrument to study policy and management issues, even in the context of higher education (Cai \& Mehari, 2015; Dumitru et al., 2014; Zimmerman et al., 2017; Tuttle \& Dillard, 2007). Its employment in research on higher education is dominated by old concepts of new institutionalism, such as the relationship between organizations and environments (DiMaggio \& Powell, 1991), the concept of organizational field (DiMaggio \& Powell, 1983), isomorphism and institutionalism focused on organizational homogeneity and stability with consideration for legitimacy, leading researchers to explore further theories, in order to eliminate the faults of this approach (Cai \& Mehari, 2015). As legitimacy for stakeholders and survival are the main reasons of organisational actions (DiMaggio \& Powell, 1983), the link between the stakeholder theory and the institutional theory seems obvious. The pressure of stakeholders on organisations binds the latter to revise their procedures as, in order to meet social expectations, "they are rewarded for doing so through increased legitimacy, resources, and survival capabilities" (Scott, 1987: 498).

The employment of the institutional theory in the context of a complex stakeholder network is a topic that has so far been little explored in literature. Therefore, our paper aims to categorize and analyse the institutional and external stakeholder pressure (translated as requirements and expectations) exerted on accounting study programs delivered by Romanian Higher Education Institutions (HEIs), in order to identify the elements towards which such pressures converge. In this line, the paper provides an answer to following empirical research questions: 
- What are the requirements and expectations of each class of external stakeholders?

- Is there any convergence between the identified expectations?

The paper approaches the seven external stakeholders - the legislator, the accreditation body, the financing authority, HEI classification/ranking agencies, other HEIs, employers, professional bodies. Students and alumni were not included in our study, as they are not only direct beneficiaries of education, but also participants in the education process, together with the academics. This view is shared by Avci et al. (2015), who find that students can be classified as external stakeholders from the perspective of the enrolment, but they will be considered internal stakeholders from the perspective of their involvement in the university's activity.

Several studies (O'Connell et al., 2015; Brewer et al., 2014; Islam, 2017), as well as a report issued by a professional body (ACCA, 2016) have recently pointed to the evolution of the accounting profession and predict dramatic changes during the next decade. In the context of predicted changes HEIs face a legitimacy gap and are gradually more under pressure from multiple institutions and stakeholders to adapt to their requirements and expectations. In the classical view of the institutional theory, universities respond to this potential legitimacy gap by acting isomorphic inside their organizational field (DiMaggio \& Powell, 1983). HEIs facing similar institutional pressures become similar to each other and have converging perceptions of how to respond to institutional pressures; in time, they adopt similar strategies or organizational practices to gain and maintain legitimacy (DiMaggio \& Powell, 1983; Dumitru et al., 2014; Grossi et al. 2020; Reale \& Seeber, 2011; Scott, 2008). The challenges that the accounting profession will need to face call for an adjustment of the accounting education, as the new context will require new competencies and skills. Our study approaches only bachelor and master study programs because they attract a greater number of students, compared to doctoral and postgraduate programs and have a significant contribution to the university's basic funding.

The study focused on the Romanian academia, which has been subject to different transformations, meant to modernise the education system, during the last decades. Romanian universities have passed from "labour-force breeding units" in line with ideological norms of communism (Mihailescu \& Vlasceanu, 1994) before 1989, to state-controlled and funded universities with an inconsistent de facto autonomy in the beginning of 1990s. They were reformed in the mid-1990s towards a marketbased HE model granted with academic autonomy. The new funding system comprised state study tuition and financial incentives for attracting external non-state funds (Dobbins \& Knill, 2009). Reforms introduced into the Romanian HE system to promote autonomy, performance-based criteria, new teaching methods have prefigured many other transformations that the Bologna process brings to the 
46 countries from the European Higher Education Area (EHEA) like new proactive internal systems of management, resource allocation, the use of European Credit Transfer System (ECTS) and the modularization of curriculum (Gvaramadze, 2008). In Romania, the Bologna process has contributed to the acceleration of the marketbased trend (Dobbins \& Knill, 2009), but according to the Bologna Process Implementation Report (European Commission, 2018), the country has experienced the strongest decrease of both the number of students, and the public expenditure on education during the last years. More, the same report points to the fact that only $39 \%$ of Romanian students are satisfied with the quality of teaching and merely $37 \%$ consider that the training provided by HEIs is appropriate, given the requirements of the labour market. These data place Romania on the last position among EU countries. Recently, the higher education system in Romania has been evaluated based on the provisions of the OECD HEInnovate review, commonly developed by OECD and the European Commission. The report points to issues like: the need for greater freedom for HEIs to introduce new educational content, identifying the appropriate key performance indicators (KPIs) to monitor progress and measure the relevance of education, training policymakers and university management to understand KPIs, and training faculty members on teaching and learning methods. All the above turned the Romanian higher education system into an attractive field for our study.

In order to reach the objective of our research, several data sources have been used. As a start, we have reviewed documents that we considered relevant to our research (laws and regulations, reports, studies, press releases etc.). We have also reviewed the websites of all the specific bodies and associations the study refers to.

As a result of our investigation, we observed a common denominator of stakeholder requirements: quality. The meaning of quality is however different to each of them. Though quality is not defined per se, it is assessed by all stakeholders, based on some predefined criteria. At the same time, we observed that satisfying all stakeholders involves all types of isomorphism: coercive, mimetic, normative, and even competitive.

The paper describes requirements and expectations issued by external stakeholders of academia and accounting study programs from Romania and links stakeholder theory to institutional theory in higher education. In terms of practice, the paper contributes by raising the awareness of responsible actors as regards the pressures exerted by stakeholders and the need to constantly adjust accounting study programs.

The remainder of the paper includes the research framework with a brief literature review on the two approached theories (stakeholder theory and institutional theory) and an analysis model, a description of the research method, as well as a presentation and a discussion of the results achieved. Some final remarks and conclusions are included in the final section. 


\section{Research framework}

Our central objective is to categorize and analyse the institutional and external stakeholder pressure (translated as requirements and expectations) exerted on accounting study programs delivered by Romanian Higher Education Institutions (HEIs), in order to identify the elements towards which such pressures converge. The research framework consists of three elements.

- we identify the stakeholders of accounting study programs by reviewing the existing literature.

- we review how institutional theory is used in the accounting education research, as this theory was broadly employed to explain the institutional pressures on organizational fields that are constantly reformed, such as higher education.

- we employ institutional and stakeholder theory, in the context of a complex stakeholder network, to develop an own analysis model for answering the two research questions.

\subsection{Stakeholders of accounting study programs}

According to Freeman (1984: 46), "a stakeholder in an organization is (by definition) any group or individual who can affect or is affected by the achievement of the organization's objectives". In other words, stakeholders are partners of the organisation, who influence or can be influenced by the organisation's strategy (Pesqueux \& Damak-Ayadi, 2012; Mainardes et al., 2012).

Stakeholder theory has been employed in research projects regarding rather business entities than HEIs. Its analysis for HEIs becomes more interesting since, in this context, the number of stakeholders is higher (Piotrowska-Piatek, 2016) and they form a more complex group (Chapleo \& Simms, 2010). Several authors sought to identify, classify or prioritize stakeholders in higher education (Burrows, 1999; Avci et al., 2015; Kettunen, 2015; Borwick, 2013), but only few papers approach the stakeholder concept in a specific context, such as a case study performed within a university (Chapleo \& Simms, 2010).

Burrows (1999) was the first to prepare a list of HEI stakeholders that included: governing entities, administration, employees, clienteles, suppliers, competitors, donors, communities, government regulators, non-governmental regulators, financial intermediaries, and joint venture partners. This list was confirmed, expanded or even adapted to different contexts by other authors (Mainardes et al., 2010; Jongloed et al., 2008; Kettunen, 2015; Labanauskis \& Ginevicius, 2017, Borwick, 2013). Yet, the importance of different stakeholder categories can vary in time (Mitchell et al., 1997). 
Additionally, literature includes several stakeholder classifications, based on different criteria. For example, Burrows (1999) identifies different stakeholder classes depending on their position (internal and external), involvement in the activity of the organisation (active and passive), the impact on the activities of the organisation (potential cooperation or threat), their stakes and influences on the institution. The internal/external stakeholder classification is the most frequent one, however primary and secondary (Maric, 2013), visible and latent (Jongbloed et al., 2008, Mainardes et al., 2013), or even commercial and non-commercial stakeholders (Melewar \& Akel, 2005) are listed with respect to higher education.

Burrows (1999) was the first to classify stakeholders as internal and external. This is the most frequently used classification (Melewar \& Akel, 2005; Avci et al., 2015; Piotrowska-Piatek, 2016; Labanauskis \& Ginevicius, 2017), even though some authors claim that, in the academia, this delimitation is not always helpful (Avci et al., 2015). More precisely, the authors point to students, who are classified as external stakeholders, from the perspective of their enrolment in the study programs, and as internal stakeholders, from the perspective of their activities within the university.

Several authors sought to identify and prioritise external stakeholders, but they did this in different contexts, in accordance with the objective of their studies. Although a large number of external stakeholder categories are referred to in literature, Watson (2012) finds that the influence of some external interested parties on the organisations is very weak, or even non-existent, so that these should not be considered stakeholders. Most authors regard employers as the most powerful group of external stakeholders (Labanauskis \& Ginevicius, 2017; Kavanagh \& Drennan, 2008; Saunders \& Zuzel, 2010; Ulewicz, 2017). Other authors find that the financing authority is a key stakeholder (Benneworth \& Jongbloed, 2009). No matter which external stakeholders are given priority, the consolidation of the relationship with them can have an important impact and bring about change (O'Connell et al., 2015).

Beyond classification criteria, identifying stakeholder requirements and expectations is important for understanding the role they play in organization development, as well as for finding a balance between the interests of the different categories. Freeman (1984) finds that organisations who manage the relationship with their stakeholders efficiently will survive longer and better than organisations who don't. In their turn, stakeholders seek to reach their objectives by means of the organisation. However, the objectives that need to be reached are not necessarily convergent (Donaldson \& Preston, 1995).

More, being aware of stakeholder expectations is the starting point in developing an appropriate quality management system (Labanauskis \& Ginevicius, 2017). As a matter of fact, numerous papers and debates focus on the definition of quality in education. Stakeholders can have different purposes and hence perceive quality in a 
different manner. Therefore, universities need to consider different perspectives in order to assure quality (ESG, 2015). Hill and Jones (1992) note that quality study programs can be provided only if stakeholders reach a consensus. This is confirmed by Ulewicz (2017), who argues that the quality of education needs to be assessed through the lens of external expectations.

Some papers investigate the impact of stakeholders on the organisation and operation of universities. Studying the case of a university from the UK, Chapleo and Simms (2010) determine the influence of stakeholders on student recruitment and satisfaction, strategy implementation, and organisation financing. The results of the research show that stakeholders exert the strongest influence on the policies and strategies of the organisation, and this influence can impact to a certain extent on the other two factors. Labanauskis and Ginevicius (2017) analyse the role of the stakeholders in university development, based on the Ishikawa's cause-and-effect diagram. They conclude that, though employers are the main stakeholder category, their influence on educational and research activities is limited.

What should be highlighted is the fact that papers approaching the relevance of accounting programs to stakeholders regard employers as the main stakeholder category (Kavanagh \& Drennan, 2008; O'Connell et al., 2015). Beyond its practical relevance, such an approach is still limited, as it ignores the expectations of other stakeholders, hence compromising the construction of a balanced quality management system of the study programs.

Our paper doesn't seek to identify stakeholders of accounting study programs. Starting from existent classifications provided by prior research (Mainardes et al., 2010; Kettunen, 2015; Borwick, 2013), we analyse the requirements and expectations of the main external stakeholder categories in a given context, and evaluate the (in)existence of a convergence between these expectations.

\subsection{The use of institutional theory in the accounting education research}

Because legitimacy towards stakeholders and survival are the main reasons for organizational actions (DiMaggio \& Powell, 1983), the combination of stakeholder theory and institutional theory seems evident, as the two theories are seen as complementary rather than competing (Deegan \& Unerman, 2011: 362).

The stakeholders' diversity is reflected in an aggregate organizational field by institutional theory which explains why organizations that are part of the same organizational field tend to adopt similar forms and characteristics (DiMaggio \& Powell, 1983). Organizations are seen in this theory as acting in a social framework composed of norms, values and taken-for-granted assumptions (Carpenter \& Feroz, 2001), a framework in which organizations comply with intra- 
and inter-organizational pressures because they expect to be rewarded by legitimacy, acknowledgement and survival capabilities.

In view of the institutional theory, this process can be explained by two dimensions: isomorphism and decoupling. The concept that best represents the process of homogenization is isomorphism, labelled by DiMaggio and Powell (1983) as "a constraining process that forces one unit in a population to resemble other units that face the same set of environmental conditions" and classified in two categories: competitive and institutional. Thus, isomorphism is the process by which organisations tend to adopt the same structures and practices and where the isomorphic change occurs because of competition on resources and customers (that is related to search for efficiency and is more relevant for those fields in which free and open competition exists) or because of coercive, mimetic or normative institutional causes. A coercive isomorphism results from pressures exerted on organizations by other organizations, on which they are dependent (DiMaggio \& Powell, 1983: 150), it can be attributed to legal, financial or political regulatory pressures. A mimetic isomorphism occurs when an organization copies the practices of another organization because of the lack of experience, poor understanding or uncertainty. A normative isomorphism arises from professionalization, the pressures exercised by educational and professional groups that develop the professional norms in the respective organizational field.

Although the institutional theory has its roots and is mainly used for studying policy and management issues, it has assisted researchers in different accounting topics like development and convergence of accounting standards (Touron, 2005; Barbu \& Baker, 2010; Dufour et al., 2014), evolution of accounting (Barbu et al., 2012; Fujii, 2016) and the role of accounting profession (Fogarty, 1996), management accounting (Covaleski \& Dirsmith, 1986; Amans et al., 2015) or governmental auditing (Gupta et al., 1994). While the reforms in higher education are often perceived as strategic and managerial responses to environmental changes (Cai \& Mehari, 2015), institutional theory became a popular instrument in the study of different organizational aspects, inclusive in higher education (Cai, 2010; Bastedo, 2009; Bastedo, 2012; Manning, 2013). There are several researchers that have employed institutional theory in business and accounting higher education as well (Etherington \& Richardsson, 1994; Mayper et al., 2005; Tuttle \& Dillard, 2007; Gonzalez-Gonzalez et al., 2009; Zhang et al., 2014; Dumitru et al., 2014; Zimmerman et al., 2017).

Institutional theory focuses on the processes by which one institution becomes dominant within the society (Mayper et al., 2005) and seeks to explain the processes and reasons for organizational behaviour, as well as the effect of organizational behaviour patterns within a broader, inter-organizational context (Guth, 2016). In the frame of institutional theory, higher education is an institution (Meyer et al., 2007) that accounts adequately for the processes of transformation of education in a society 
and represents the rules of the game for universities which are part of a complex higher education organizational field (DiMaggio \& Powell, 1983; Scott, 2015). However, this theory has given little attention to defining the boundaries of the organizational field (Scott, 2008), being approached as an aggregate, which is a recognized area of institutional life (DiMaggio \& Powell, 1983: 148).

Defining components of the organizational field is a huge task in higher education (Frolich et al., 2013), as there are many actors and stakeholders involved or interested in the sector, besides universities. Moreover, the increasing diversity of stakeholders challenges the delimitation of organizational sub-fields. Looking at the latest developments, we can see that new bodies have been set up at national and international level to develop educational and generally valid quality standards (Bologna Treaty- European Association for Quality Assurance in Higher Education - ENQA), Romanian Agency for Quality Assurance in Higher Education - ARACIS) or sector-specific standards (International Association for Accounting Education and Research - IAAER, International Accounting Education Standards Board - IAESB) that led to the widening of the organizational field of higher education and (see figure 1) influencing organizational behaviour and practices.

Figure 1. Organizational field of HEI

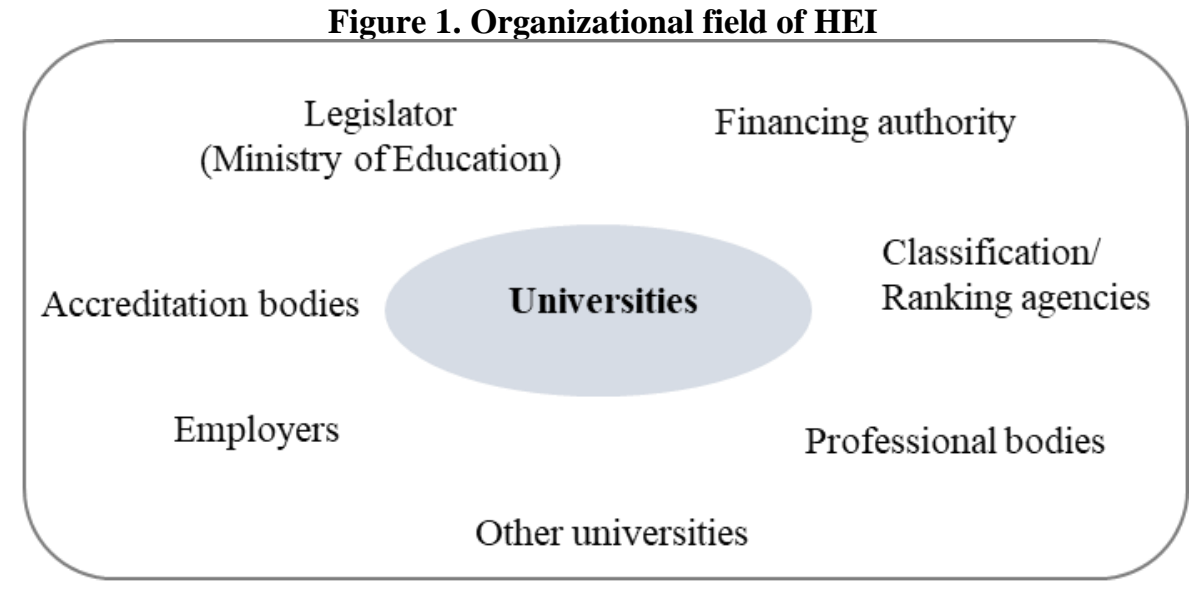

In order to reach legitimacy, the practices adopted by organizations tend to become homogeneous and to conform to what particular powerful groups consider to be "normal" (Larrinaga-Gonzalez, 2007). Over time universities responded to different institutional changes and adapted and homogenized their structure, funding, educational programs, curricula, teaching methods, among others, in order to respond to changing social and institutional pressures and expectations of different stakeholders (Curaj et al., 2015; Dobbins \& Knill, 2009; Dumitru et al., 2014; Etheringhton \& Richardson, 1994; Gonzalez-Gonzalez et al., 2009). 
The second dimension - decoupling - refers to the situation in which the formal organizational structure or practice is separate and distinct from actual organizational practice. An organization in a highly institutionalized environment, such as higher education, may face inconsistencies between demands for efficiency and the need to conform to the rules of the institutional context (Meyer \& Rowan, 1977).

The concept of isomorphism has been applied in accounting education and research. When investigating how Canadian accounting education adapts to environmental requirements, not only coercive, mimetic and normative institutional pressures have been identified, but also competitive ones (Etheringhton \& Richardson, 1994). Typically, the state and those stakeholders who allocate funds to universities exert coercive pressure, while professional and academic associations exercise normative pressure, and opinion leaders exert mimetic pressures.

Gonzalez-Gonzalez et al. (2009) analysed both competitive and institutional isomorphic pressures to introduce a policy of incorporating skills in business administration and accounting education in Spain and evidence that Spanish universities adopt an "avoidance" strategy to change. To highlight how the curriculum of accounting programmes at a Romanian university was adjusted according to the expectations of stakeholders, Dumitru et al. (2014) have applied neoinstitutional theory by using the three mechanisms of isomorphism. Changes in university accounting education have been studied also from an institutional perspective by Zhang et al. (2014), in order to analyse the key domestic and external factors impinging on university accounting education system change in China since 1949. Gonzalez-Gonzalez et al. (2009) evidence different isomorphism as means to explain the change process and its implications for accounting education and accounting educators in Spain.

Helliar (2013) states the necessity of a consistent and comparable education at global level. By using an institutional theory perspective, the author maps out a future plan for accounting education and proposes a world model that fits all nations. The global accounting education in her scenario should adopt similar learning objectives that should be embedded in international education standards (IES) of International Accounting Education Standards Board (IAESB).

Not only education, but also accounting research has been studied by applying institutional theory. Tuttle and Dillard (2007) found that mimetic, coercive and normative isomorphism are significant within the organizational field of accounting research in USA, but the normative pressures have the strongest significance in the actual context.

The other dimension of the institutional theory is not so often discussed in accounting higher education articles. Debating the actual connection of accounting research and accounting practice, Zimmerman et al. (2017) identify an "ironic" effective 
decoupling: the need for academic accounting to appear applied and not be truly committed to practice. In order to be accredited, academic accounting departments in the USA need to demonstrate interaction with the practice community (Zimmerman et al., 2017); that is why many accounting departments have practitioners in their advisory boards. On the other hand, people with practice credibility that are brought into higher education are then marginalized by the field's social organization.

The last developments in institutional theory like institutional entrepreneurship, institutional work and institutional logics came as a response to the debates and criticism that new institutionalism is static, and not able to predict change (Koning, 2016), treats organisations as similar, or at least as though any differences are irrelevant for the purposes of the theory (Greenwood et al., 2014), explains the homogeneity or stability of organisational arrangements, in a specific organizational field, but ignores the roles of actors in institutional change (Cai \& Mehari, 2015). Different authors, such as Friedland and Alford (1991), Scott et al. (2000), Thornton et al. (2012), Greenwood et al. (2014) put forward the institutional logics, which assumes differences between organizations and seeks to explain them. Institutional entrepreneurship and institutional work introduced by DiMaggio (1988) was emphasized in the last years by Battilana et al. (2009), Zietsma and Lawrence (2010), Tracey et al. (2011).

Applying institutional theory in the context of a complex network of stakeholders is a less explored topic in literature. Often the stakeholders are approached by this theory as a pluralistic aggregated organizational field, and more rarely unpacked (Frølich et al., 2013). However, both individual and collective actors play varying roles (Scott \& Biag, 2016), but together they form and participate in a common "local social order" (Fligstein, 2001) in which universities are important centres for the development of organizational norms (DiMaggio \& Powell, 1983). Therefore, our work explores the pressures (translated by requirements and expectations) exerted by the stakeholders of the accounting programs offered by universities.

\subsection{Changes and reforms in the Romanian HE. Research analysis model}

During the last decades the universities have gone through major transformations, being in permanent search for social legitimacy, acknowledgement and survival. Since 1990, Romanian Higher Education has undergone several important changes and reforms (Birzea, 1997; Curaj et al., 2015; Dobbins \& Knill, 2009; Dragoescu, 2013; Dumitru et al., 2014; Nicolescu, 2002). Institutional theory usually refers to several perspectives that explain the relationship between institutions and different stakeholders, assuming that not only institutions are affected by stakeholders' actions, as well as by their perceptions, behaviour, decision-making or power, but stakeholders are in their turn influenced by these institutions. According to Meyer 
and Rowan (1977), institutionalism focuses on the need of organizations to adapt to their institutional environment, such as norms, rules and expectations and this transformation cannot be so smooth and rapid. Lack of success to act in accordance with rules, norms and expectations may conduct to conflicts, loss of legitimacy, loss of recognition or even questioning their survival. In its historical approach, the institutional theory seeks to explain institutions by reference to the past, focusing on their specific features, because institutions are part of a set of causes and effects. Hence, timing and path dependence affect institutions, and shape social, political, economic behaviour and change (Hall, 2010; Hall \& Taylor, 1996). Major shocks, as the change from communism to capitalism in Romania in the early 1990, are important factors that lead to various institutional changes. The shock received by the society, by every institution, and in particular by HEIs generates "critical connections", whereby certain path dependencies were created. HEIs play a strategic role in society and their specific nature allows them to endure over time, however external events affect their institutional change. The transformations and reforms that Romanian HE passed through from the fall of communism in 1990, until the enactment of the new Education Act in 2011, have brought many institutional changes which affect the transition of Romanian HE from a state-centred model to a market-oriented model (Dobbins \& Knill, 2009; Dobbins et al., 2011). These institutional changes, as identified in prior literature, are detailed in Appendix A and briefly presented below.

From 1990 to 1997, the HE reform evolved slowly. Universities had an inconsistent de facto autonomy, were state-financed and state-controlled. Some private universities were established; unlike public ones, these were financially autonomous. Though some steps were made in updating curricula, textbooks and teaching methods, the reform stagnated, given the lacking entrepreneurial skills of university managers (Nicolescu, 2002).

An important step forward was taken in 1998, with a long list of institutional changes. HEIs benefited from both academic, and financial autonomy. Multiple financing principles were introduced; besides the core financing (a lump sum given to universities according to the number of student equivalents), universities received complementary funding for research and investments. Tuition fees and own income, as well as sponsorships or donations, added to the existing funding. A two-step accreditation of HEIs was introduced and several specialized bodies were established, either within or independent of the Ministry of Education, in order to advise and assist the Ministry in the implementation of the reform. The Bologna Declaration was signed in 1999, aiming to align higher education with the emerging pan-European system.

A new public financing mechanism, with two components, was implemented between 2000-2006. The main component consisted of block grants, allotted according to a per capita cost-differentiation formula and based on bilateral contracts 
between the Ministry of Education and the HEIs; the second part was a differential financing based on a qualitative component (i.e. calculated by considering some qualitative indicators, which were updated regularly). Specific regulations were adopted, driven by the implementation of the Bologna process. In 2005, higher education study programs were organized in three cycles: bachelor, master and doctoral studies. The European Credit Transfer and Accumulation System (ECTS) became mandatory for all universities. An independent public institution with competences in accreditation, quality review and quality assurance of HEI was established: the Romanian Agency for Quality Assurance in Higher Education (ARACIS).

From 2007 to 2010, both the Ministry of Education and the HEIs strengthened their focus on institutional performance. A new reform was foreshadowed; the state of Romanian research and higher education was analysed and the results were publicly debated by all political parties and key stakeholders. Curriculum, HEI management, full university autonomy, university classification based on their mission statements and achievements, and study program ranking were some of the main issues identified for further reform within the strategy "Education and Research for the Knowledge Society" (Presidential Commission 2008). A new legal framework to support new developments and facilitate progress was required. As a result, the new National Education Act was adopted in January 2011.

With it, the relationship between universities and their external stakeholders gained in importance inside the legislation concerning HE. Therefore, the National Education Act no. 1/2011 is the starting point of our study. In our analysis, we employ both stakeholder, and institutional theory and respond to following research questions:

- What are the requirements and expectations of each class of external stakeholders?

- Is there any convergence between the identified expectations?

Stakeholder theory refers to diversity and different relationships between stakeholders and organizations. In its managerial approach, the stakeholder theory seeks to explain the stakeholder power and how a stakeholder's relative power affects the ability to "coerce" the organization into complying with stakeholder expectations (Deegan \& Unerman, 2011: 353). In order to maintain its legitimacy, acknowledgement and survival, an organization will manage its various groups of stakeholders in a different manner. The expectations of different stakeholders will impact the activity of HEIs; these will not respond to all stakeholders equally, but rather respond to those stakeholders that seem to be more powerful (Bailey $e t$ al., 2000). 
Institutional theory seeks to explain the development of organizations and the way organizations compete for social legitimacy, acknowledgement and survival. Due to institutional pressures (coercive, normative, mimetic) and/or competitive pressures, organizations become increasingly similar within their organizational field, as they need to conform to the expectations of their environment. This process, called institutional isomorphism by DiMaggio and Powell (1983), explains how organisations tend to adopt similar structures and practice and move towards homogeneity. In its historical approach, the institutional theory explains that organizations are strongly anchored in their past, they are part of a set of causes and effects, therefore timing and path dependence affect organizations and shape their social, political, economic behaviour and change. However, changes in regulations don't immediately change practice or mentalities, because the past "matters" and organizations tend to resist change. On the other side, universities are subject to multiple influences and consequently to multiple logics, reflecting the institutional complexity within the organisational field, which is characterised by stakeholders with multiple views and interests.

An inductive model of pressures on the organizational field of HEI, based on the institutional theory and the stakeholder theory is shown in figure 2.

Figure 2. Pressures on the organizational field of HEI

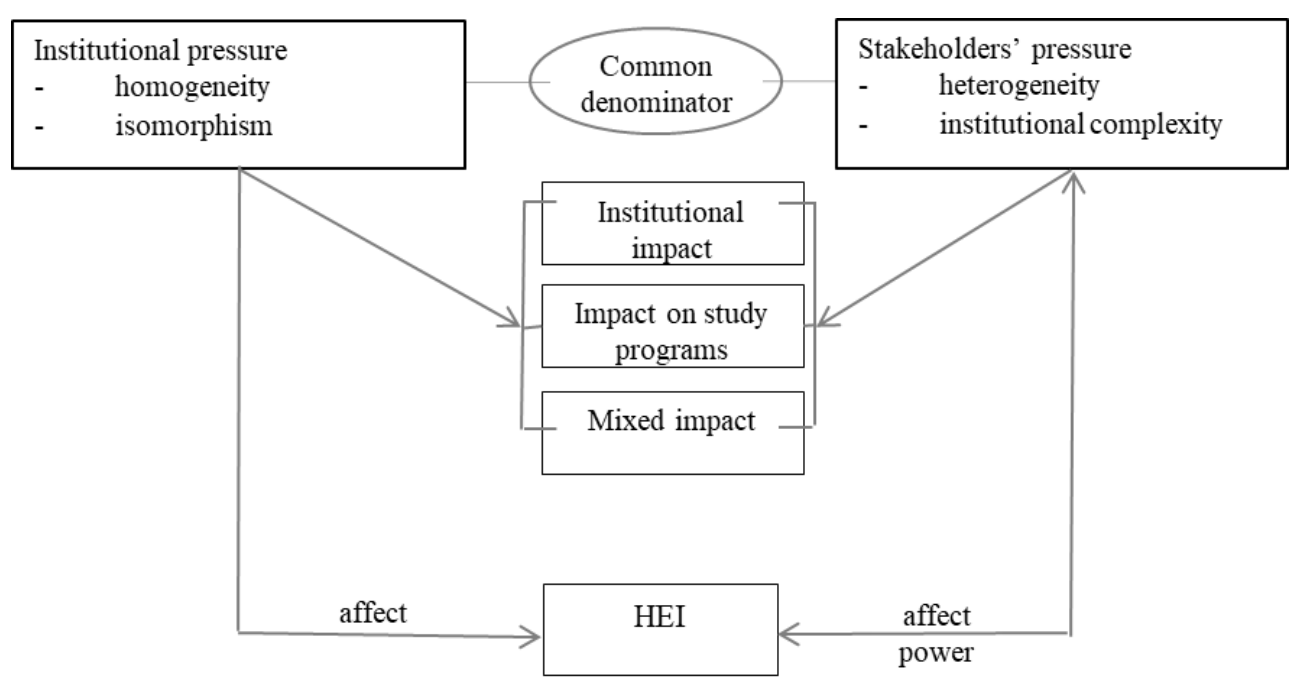

HEIs are affected by institutional pressures and respond to stakeholder requirements and expectations in their organizational field, by moving towards homogeneity, while historical footprints continue to shape them and influence their response to institutional changes. On the other hand, stakeholder identification and classification are essential to universities, as every category needs a different strategy in its approach (Avci et al., 2015). Those stakeholders that exert more power on the 
organization will be prioritized. The pressures (translated as requirements and expectations) exerted by external stakeholders of accounting study programs delivered by Romanian HEIs may have elements towards which such pressures converge and we assumed that these pressures exerted on universities and on the relationship between university and its external stakeholders may have different levels of impacts: institutional impact, impact on study programs or mixed impact.

\section{Research design / methodology}

The objective of the study is to explore the requirements and expectations of each external stakeholder category of accounting higher education in Romania, as these can turn into pressures that different stakeholders exert on HEIs. In order to address our research topic, we use an inductive approach. The study was performed through the lens of the institutional theory, and considered the types of isomorphism identified by DiMaggio and Powell (1983).

In order to select the external stakeholders to be considered, we started from Borwick (2013), and nominated seven categories: the legislator, the accreditation body, the financing authority, HEI classification/ranking agencies, other HEIs, employers, and professional bodies. The two research questions that we sought to answer were the following:

- What are the requirements and expectations of each external stakeholder category?

- Are the identified requirements and expectations convergent?

In order to answer the two questions, we performed a review of relevant public official documents. The information sources were diverse and heterogeneous, in accordance with the heterogeneous character of the stakeholders who issued them, or whom the documents refer to (see Appendix B).

Starting from previous research that mentions the link between HEI's quality of study programs and stakeholder expectations (Hill \& Jones, 1992; Ulewicz, 2017; Beerkens \& Udam, 2017), our review explored external stakeholder requirements and expectations through the analysis of quality criteria, defined for different purposes. Searching for specific keywords was difficult and the only common keyword identified in some of the documents was "quality". Due to the diverse and complex content of the documents, a complete and deep reading was required to observe the requirements and expectations that implicitly refer to quality, where the word "quality" was not explicitly mentioned.

The starting point of our study was the National Education Act no. 1/2011. We analysed the Education Act in full, in order to understand the general framework for the organization and functioning of the educational system in Romania. However, 
this document does not explicitly define requirements for the quality of study programs, but refers to different quality standards. These standards regard the accreditation, funding and ranking of universities and study programs. Therefore, in the next step, we reviewed the guidelines and methodologies issued for each of the three mentioned objectives, namely accreditation, financing and classification. We tracked and structured the quality criteria (translated into requirements and expectations) set for each objective.

In order to identify the expectations of the professional bodies, we analysed the websites of the two professional accounting and auditing bodies involved in accounting and auditing in Romania, searching for documents or information to identify the forms of collaboration between them and the HEI at the level of study programs, as well as examining the requirements of these bodies for the entry exams as trainees. With respect to the same category, we investigated the expectations of an international professional body, whose collaboration with the academia has been enhanced lately, i.e. the Association of Chartered Certified Accountants (ACCA). The requirements of professional bodies are translated into knowledge and skills that accounting study programs need to develop for graduates.

Pressures exerted by other universities were investigated based on the operating framework of the Universitaria Consortium, a HEI Consortium consisting of the five largest universities from Romania, as well as based on the operating framework of the Erasmus program. In this regard, we have consulted the websites of the five public universities that form the Universitaria Consortium. We have looked for internal structures and regulations regarding quality.

For defining the scope of employer expectations, we reviewed the ACCA report entitled "Drivers of Change and Future Skills", drawn up on the basis of a study conducted by experts from around the world. Due to business internationalization, we appreciate that the results of this study may also be applicable to employers in Romania.

\section{Results and discussions}

The-changes in HE governance models over the last decades have affected the organizational structure of the universities, their management, personnel and funding approach and changed the relationship between universities and their external stakeholders (Dobbins \& Kwiek, 2017).

Given the heterogeneous character of the stakeholders, we considered in this paper that grouping them by the scope of their impact would be useful and help our results to gain in clarity. Hence, we identified three groups of stakeholders: 
- The legislator and the financing authority are stakeholders with an institutional impact, i.e. they make an impact on HEIs;

- The accreditation body, the classification/ranking agencies, and other universities are stakeholders with a mixed impact, both on HEIs, and on study programs;

- Employers and professional bodies are stakeholders that have an impact only on study programs.

The current section will be further on structured such as to respond, in turn, to the two research questions. The first three paragraphs present the main results of the analysis on requirements and expectations of each stakeholder group nominated above, and provide an answer to the first research question. The fourth paragraph presents the impact of the identified requirements and expectations on the HEIs or the study programs, as well as the existent points of convergence between these, and provides an answer to the second research question.

\subsection{Stakeholders with institutional impact}

\subsubsection{The legislator}

The vision of the legislator, as stated in the National Education Act no. 1/2011 is to promote "an education oriented towards values, creativity, cognitive capacity, volition capacity and capacity for action, fundamental knowledge, as well as knowledge competencies and abilities of direct usefulness, in profession and society" (art. 2, para. 1).

The competencies that education needs to provide will be employed by the beneficiaries of education both 'for personal development and fulfilment', and in the context and for the sake of the society they live in: "social integration, ... employment and participation in the operation and development of a sustainable economy" (art. 4). As such, society turns into a directly addressed stakeholder in the education of a given individual, and the outcome of education will be perceived not only by direct beneficiaries, but by the whole structure they live in.

The different stakeholders are considered not only as addressees of the education output, but as partners in defining the inputs, too. When designing national strategies in education, the Ministry of Education advises with significant education associations and structures, public administration authorities, the business environment and non-government organisations supporting education programs.

Education is governed in Romania, according to the law, by several principles, among which we find the principle of quality. Though all legal acts in the field of education regard quality as a central point of any decision on delimiting, structuring, operating or financing education providers, the concept is nowhere defined per se, 
but by reference to the expectations of third parties, or to external standards. The quality principle states that "educational activities are guided by standards of reference, and national and international good practice" (art. 3, pt. b), and the quality of education is defined as "those characteristics of a study program, or professional qualification program, through which the quality standards, as well as the expectations of the beneficiaries are met".

The legislator establishes a clear connection between quality and the expectations of beneficiaries, whereas the latter are classified in two categories. Direct beneficiaries are individuals educated by the system, while their families, employers, the local community and, broadly, the whole society are regarded as indirect beneficiaries. The requirements of the legislator are imperative and create the organisational context through a coercive isomorphism.

The mission of higher education is defined by the National Education Act on two different directions: education and scientific research. The quality of education and research performed in HEIs is evaluated by different governmental institutions, in different contexts and with different purposes. We speak of three distinct evaluation processes:

a) External evaluation of academic quality for the purpose of issuing a temporary operating license, or an accreditation to HEIs and study programs;

b) Evaluation for the purpose of financing the activity of HEIs;

c) Evaluation for the purpose of ranking study programs and classifying HEIs.

Quality is proven by meeting several standards and fulfilling the expectations of beneficiaries. A clear identification of these expectations is hence required.

\subsubsection{The financing authority}

Under the National Education Act, art. 221, para. $3 \mathrm{~b}$ and c, public higher education is financed from public funds, in accordance with "the assurance of quality ... at the level of the standards of the European Higher Education Area, in order to provide the education of human resources and the personal development as citizens of a democratic, knowledge based society". The authority in charge with funding the activity of HEIs is the National Council for Financing Higher Education (CNFIS).

There are three types of public HEI funding: (1) basic funding; (2) supplementary funding; and (3) funding for institutional development. The basic funding of public universities is provided from public funds, through study grants calculated based on the average cost per equivalent student, per field, course of studies and teaching language. Funds are allocated primarily to "those fields that assure the sustainable and competitive development of society and, within the field, primarily to programs that are best ranked in terms of quality, whereas the number of study grants allocated to a program may vary according to the place of the program in this ranking" (art. 223, para. 4). 
The supplementary funding is meant to stimulate excellence among HEIs and study programs and is granted based on several criteria, established by the National Council for Financing Higher Education and approved by the Ministry of Education. The quality indicators that are employed are classified into four categories, as follows (Order of the Ministry of National Education no. 3047/2018): (i) The teaching/learning process; (ii) Scientific research/ creation of art/sport performance; (iii) International orientation; and (iv) Regional orientation and social fairness of the higher education institution. Each class has a specific weight in the total value of the quality indicators, as follows: scientific research/ creation of art/sport performance $40 \%$, teaching/learning process $-30 \%$, regional orientation and social fairness $-20 \%$ and international orientation $-10 \%$. The four categories consist mainly of quantitative indicators, like the ratio between the number of master students and the number of bachelor students; the number of teachers aged up to 40 and the total number of teachers; the ratio between the number of students and the number of teachers; the proportion of international students enrolled in the study programs; the proportion of student mobilities; the contribution of the university to the scholarship fund etc.

The funding for institutional development is allocated either for the institutional development of recently merged universities, or for financing specific projects of institutional development aiming at promoting new study programs, increasing the institutional capacity, enhancing the quality of teaching, developing the research infrastructure, maintaining the relationship with the local and/or regional community, social inclusion and/or the internationalisation of higher education.

As funding is granted on condition that HEIs meet the criteria enunciated by the financing authority, the impact on the institution is direct and, consequently, the requirements of this stakeholder category are imperative.

\subsection{Stakeholders with a mixed impact}

\subsubsection{Accreditation bodies}

For the awarding of a temporary operating license or an accreditation, the evaluation is performed by The Romanian Agency for Quality Assurance in Higher Education (ARACIS) or by another agency for quality assurance, from Romania or from abroad, listed in the European Quality Assurance Register for Higher Education (EQAR). The same authority undertakes a periodic evaluation of the academic quality of education and research services (Ordinance no. 75/2005).

The external evaluation of academic quality, performed by ARACIS, is regulated by the Methodology for external evaluation, the standards, reference standards and the list of performance indicators. This methodology is further developed by the Guide 
for evaluation activities of the quality of academic study programs and higher education institutions. The ARACIS Methodology and Guide assure the conformity with the European Standards and Guidelines for Quality Assurance in Higher Education (ESG). For a clear identification of its addressees, the Methodology nominates, as beneficiaries of higher education, students, employers and, broadly, the whole society.

In evaluating quality, ARACIS considers three domains in the organisation and operating of a HEI:

a) The institutional capacity, referring to the organisation, management and administration system of the institution, including the physical resources, financial resources and human resources. What is evaluated is the extent to which the organisation is coherent and sustainable, the physical and financial resources are sufficient for the continuous operation of the institution on short- and middle term, and the human resources are appropriate for fulfilling the mission and reaching the objectives of the institution.

b) The educational effectiveness refers to "the student focused design and organisation of the teaching, learning and research processes, in terms of content, methods and techniques, resources, recruitment of students, teaching and research personnel, in order to achieve those results in teaching and research that were pursued through its mission, which needs to be clearly stated" (Methodology for external evaluation, the standards, reference standards and the list of performance indicators of The Romanian Agency for Quality Assurance in Higher Education, part 1, para 1.5) and is evaluated based on four quality criteria: (1) The content of study programs; (2) The results of teaching; (3) The research activity; and (4) The financial activity of the organisation.

The content of the study programs needs to be designed in accordance with the expected results of the teaching process and must correspond to an academic qualification, established in conformity with the National Qualification Framework, respectively with the Qualification Framework from the European Higher Education Area. The study programs shall also contain "topics leading to the achievement of transversal competencies, like asserting the personality of students in society, communication, foreign languages, teamwork, training students in the spirit of European values, issues regarding the sustainable development of the society, the promotion of democracy, of the intercultural dialogue, the compliance with law, responsibility in pursuing the profession etc., that are susceptible to influence their personal development and can be employed in their future careers" (Methodology for external evaluation, the standards, reference standards and the list of performance indicators of The Romanian Agency for Quality Assurance in Higher Education, part 2, para 2.2). 
The results of teaching are evaluated based on 5 performance indicators: (i) employability; (ii) enrolment in further academic education; (iii) student satisfaction in terms of professional and personal development provided by the university; (iv) student-focused teaching methods; and (v) student career guidance.

We observe that, in evaluating the quality of teaching results, the capitalization of the achieved academic qualification is measured in terms of employability and enrolment in further academic education. In this context, the minimum ARACIS requirement is that, within one year after graduation, at least $50 \%$ of the graduates are employed, respectively at least $20 \%$ of the graduates from the last two years are enrolled in a master study program, irrespective of the field.

Student satisfaction in terms of professional and personal development is assessed based on a survey, whereas the minimum requirement is that over $50 \%$ of the questioned students provide a positive feedback in this matter. The fourth indicator employed in the quality evaluation of teaching results actually refers to a prerequisite of achieving student satisfaction, i.e. student-focused teaching methods. These should involve a partnership between students and teachers, within which each of the two parties takes responsibility for achieving the results, by employing appropriate methods, instead of focusing on traditional information delivery. Finally, student career guidance needs to be provided both by teachers, and by at least one career guidance centre of the university.

In evaluating the quality of research, ARACIS reviews the existence of long-term strategies, respectively medium- and short-term research programs, the observance of an academic code of ethics and integrity, as well as of research quality standards, and the capitalization of research results through publication.

In evaluating the quality of the organisation's financial activity, ARACIS reviews the existence of a budget and an appropriate accounting.

c) Quality management refers to those strategies, structures, techniques and operations through which the institution shows that it evaluates its own performance in assuring and enhancing the quality of education, and its information systems reveal the results that were achieved in terms of teaching and research.

Subject to evaluation are quality assurance strategies and procedures, the procedures employed in the initiation, monitoring and periodic revision of programs and activities, the objectivity and transparency of the evaluation of teaching results, the evaluation procedures of teachers, the accessibility of appropriate learning resources, the database on internal quality assurance, the transparency of public information, the functionality of the structures assuring the quality of education, the regular external assurance of education quality. 


\subsubsection{Classification/ranking agencies}

Study programs are ranked and HEIs are classified in Romania by a consortium, consisting of ARACIS, student representatives, the National Council of Scientific Research (CNCS), the National Certification Council of Academic Titles, Diplomas and Certificates (CNATDCU), and an international body with specific competencies. Subsequent to this evaluation, universities are classified in three categories, in accordance with their focus: (i) education; (ii) education and research, or education and creation of art; and (iii) advanced research and education.

According to Government Decision no. 789/2011, all universities that hold an accreditation, or a temporary operating license, either public, private or confessional, are subject to classification. In the same line, all bachelor and master study programs provided are subject to ranking. There are five criteria that can be employed in this process, regarding: (a) teaching and learning; (b) research; (c) creation of art, where appropriate; (d) the relationship between the university and the external environment; and (e) the institutional capacity. The cumulative consideration of all five criteria is not mandatory, however the classification of HEIs will rely at least on the research criterion, and the ranking of the study programs will rely at least on the first two criteria, i.e. teaching and learning, respectively research.

According to the only official ranking so far (issued in 2011), 12 HEIs were classified as focused on advanced research and education, 22 as focused on education and research, 8 as focused on education and creation of art and 48 as focused on education. We need to specify that not all the 90 HEIs included in the classification were public. As for accounting study programs, 9 of the accounting program providers were ranked $\mathrm{A}$ (the best category), 7 were ranked $\mathrm{B}, 10$ were ranked $\mathrm{C}, 5$ were ranked $\mathrm{D}$ and 9 were ranked $\mathrm{E}$ (the weakest category).

International ranking agencies rely on roughly the same criteria. They prioritise indicators regarding research, too.

\subsubsection{Other universities}

Given the European system of credit transfer (ECTS), universities need to harmonize their study programs to a rather high extent, in order for student exchanges to be recognized at the home university.

Collaborations between universities are little regulated in Romania. Yet, the largest 5 Romanian HEIs established the Universitaria Consortium, aiming to achieve "cooperation between the partner universities, for the purpose of enhancing the quality of research and teaching, which will lead to a national and international acknowledgment of their prestige, as well as to their ranking as reference universities in Europe, initiating the improvement of the regulation framework of 
higher education and academic research, and defining academic study programs, associated standards, as well as titles and qualifications achieved through graduation, in a consistent manner" (Statute of the Universitaria Consortium).

Collaborations with universities from abroad are most often Erasmus funded. The Erasmus program facilitates the access of students and teachers to the study programs of partner universities, hence supporting the internalization, which is a significant criterion in the distribution of funds for institutional development.

Besides the need to collaborate in order to correlate the study programs they provide, the pressure of other universities is sensed as a result of the competition between different HEIs, in the attempt to attract students. In this context, universities are bound to adjust their educational offer, in accordance with the demands of the society and labour market, and they need to prepare promotion strategies, as well as strategies to attract and keep students, by means of extracurricular projects.

\subsection{Stakeholders with an impact on accounting study programs}

\subsubsection{Employers}

With globalisation, there are no significant differences between the expectations of the employers from Romania or from abroad. Starting from the main drivers of change in the current society - globalisation, complexity and technology - the International Federation of Accountants (IFAC, 2011) identifies four key roles to be played today by professional accountants: creators of value, enablers of value, preservers of value, and reporters of value. As such, it is expected that employed professional accountants hold competencies that correlate with the factors of sustainable organisational success, i.e. customer and stakeholder focus, effective leadership and strategy, integrated governance, risk and control, innovation and adaptability, financial management, people and talent management, operational excellence, effective and transparent communication.

Though they are vital, technical skills are no longer enough to deal with the current business environment. To an equal extent, professional accountants will need "softer skills concerned with interpersonal behaviours and qualities", but also IT and communication skills, both in the meaning of foreign languages, and narrative communication (ACCA, 2016). The same study dated 2016 takes stock of the competencies and skills that will be regarded as essential in the next 5-10 years in the main accounting areas: audit and assurance; corporate reporting; financial management; strategic planning and performance management; tax; governance, risk and ethics. Besides technical knowledge like laws and regulations, reporting the financial performance of entities, financial instrument valuation, international trade and finance etc., competencies like professional scepticism and critical thinking, 
communication, writing reports and other documents, holistic performance management and professional ethics are needed. There are also cases in which accounting jobs require technical knowledge from other fields, like mathematics, statistics, or less common foreign languages (Albu, 2013).

At the same time, several employers develop own training programs or require an additional qualification, beyond the academic graduation. This is the case of multinationals, or top positions, where an international qualification, like ACCA or CIMA, is required (Albu, 2013).

\subsubsection{Professional bodies}

The main accounting professional bodies in Romania are The Body of Expert and Licensed Accountants (CECCAR) and The Chamber of Financial Auditors of Romania (CAFR), both affiliated to or partner of international bodies like IFAC or ICAEW. Their mission is to organise and monitor the activity of expert accountants, licensed accountants and, respectively, financial auditors. Their relation to academia is constructed at the level of bachelor and master study programs that provide the professional basis on which professional bodies build their own further education programs.

In this line, CECCAR signed collaboration protocols with the HEIs, based on which graduates of specific master programs were exempted from the entry exam as trainees. The protocols nominated the subjects that needed to be included in the curriculum of the master programs, as they allowed the examination of professional knowledge. In its turn, CAFR signed protocols with several HEIs, granting exemptions from the entry exam as trainees to graduates of specific master programs, whose curriculum matched the curriculum of the entry exam as trainees in financial audit. However, given the provisions of Law no. 162/2017 which reconsidered the auditing profession, the protocols that allowed exemptions from the entry exam as trainees in auditing were no longer applicable starting with 15 July 2018.

More, further education programs provided by the two bodies employ academics as lecturers. This allows the consolidation of the relationship between academia and professional bodies and provides two major benefits for HEIs: (a) they contribute to the enhancement of education quality, as they bind teachers to pay permanent attention to the needs of the profession; and (b) through professional bodies, HEIs get closer to the needs of the business environment.

ACCA has lately become a partner of the Romanian academia, through the accreditation of study programs. Currently, four bachelor and seven master accounting programs have an ACCA accreditation in Romania. In order to gain an accreditation, universities need to adjust the syllabus and the evaluation conditions 
of certain subjects, so that graduates acquire competences that match the requirements of ACCA. These competences can be embedded in the curriculum of the accredited programs. Hence, the programs will be better linked with the requirements of the labour market and the international trends.

As for professional bodies, their influence on accounting study programs is a direct one, at the level of the curriculum, the syllabi and even the evaluation. As a result of our analysis, we observed that the two Romanian professional bodies focus on technical knowledge and competences, while ACCA has a rather holistic approach in terms of competencies.

\subsection{Discussions on the impact of stakeholder expectations}

We categorized and analysed the pressures exercised by the above seven stakeholders of higher education in accounting: the legislator, the financing authority, the accreditation body, the classification/ranking agencies, other universities, the employers and the professional bodies, seeking to find an answer to the two research questions.

The diversity of stakeholders and their competing pressures on universities have increased over time due to the numerous institutional changes (see appendix A). As in the early 1990 Romania had a state-centred model of HE (Dobbins \& Knill, 2009), the central role belonged to Ministry of Education who exerted a strong coercive isomorphic pressure. During the reform of $\mathrm{HE}$ and its transition to a market-centred model, universities faced growing and extended pressures, partly because of the more recent established stakeholders that joined HEI organizational field, partly because of the variety of their requirements and expectation (see appendix C). In order to respond to different coercive, mimetic and normative institutional changes the Romanian HEIs adapted and homogenized their organization structure, funding, educational programs, curricula, teaching methods, research infrastructure.

As for the first question, we can observe that all stakeholders require or expect quality in education. Still, inside the complex organizational field of higher education, each stakeholder perceives quality in a different manner. In order to reach and maintain legitimacy, universities adapt and homogenize their accounting study programs to answer and conform to what particular stakeholders consider to be "normal" (Larrinaga-Gonzalez, 2007), because HEIs as parts of the same organizational field tend to adopt similar forms and characteristics (DiMaggio and Powell, 1983).

The analysis of the different requirements and expectations, based on public documents, provides the answer to the second question and shows that these are not always convergent. As a result of our investigation, we observed a common denominator of stakeholder pressures: quality. However, the meaning of quality is different to each of them. 
The position of the legislator is neutral. What the law aims at is quality, however quality is not defined per se, but by reference to the expectations of the beneficiaries. The beneficiaries of education are nominated individually in a first stage - the educated individuals, their families, the employers, and the local community. As a last beneficiary, the legislator points to the society as a whole. The legislator has similar expectations of all universities and exerts a coercive isomorphism; for maintaining legitimacy, universities have to respect the quality principle defined in the National Education Act. Actually, the quality of education, in the view of the legislator, means its capacity to meet the expectations of the whole society. Hence, the statement of the legislator is not at all precise.

The accreditation body, the financing authority and the national classification/ranking authority are virtually representatives of one broad stakeholder: the public authority. Nevertheless, there is only a partial convergence between their expectations. The accreditation body evaluates HEIs based on several criteria, whereas the analysis is structured on three areas: institutional capacity, educational effectiveness and quality management. Special attention is paid to the educational effectiveness, and within it to the quality of teaching results, measured amongst others based on employability and student satisfaction. Research quality is regarded merely as a component of educational effectiveness, not as an individual area. By contrast, the financing authority focuses primary on research, when it comes to granting supplementary funding, meant to promote excellence.

Similarly, the classification and ranking systems focus on research. The impact of these classifications on national higher education is complex. Firstly, rankings attract the attention of decision makers in education, as they are perceived as symbols of national and international achievements. Secondly, rankings can enhance competition between universities, as low ranked HEIs perceive them as weapons they lack in the academic battle. Thirdly, classifications contributed to the creation of a financing system that promotes mainly performance. Nevertheless, the better funding of high ranked universities broadens the gap between these and low ranked universities, with a general impact on the latter's performance.

ARACIS and the financing authority are powerful external stakeholders, who may affect the survival, legitimacy and viability of Romanian universities. Both the accreditation bodies and the financing authority exert coercive forces on universities. They make HEIs become more similar in structure and adjust accounting study programs, in order for these to respond to quality requirements and quality performance indicators defined by the two stakeholders. The financing authority and the national accreditation body explain quality in education and research in more detail, compared to other stakeholders, but their views on quality are not necessary similar. Stakeholder expectations don't need to converge in every respect. Yet, the divergence in describing and measuring quality, as well as the use of different performance indicators result in a high coercive pressure on universities. 
Though rankings are, to a certain extent, subjective and contestable, by reason of unclear methodologies, they can't be ignored, due to their impact on the institutional behaviour and on those who want to benefit from academic programs. The results of any classification or ranking are public. This impacts, on the one hand, on the attractiveness of universities or study programs to students, and on the other hand on university funding. The pressures of ranking agencies bind universities to comply with the ranking criteria. Seeking to improve their ranking for getting better funding and be more attractive, universities improve upon institutional practices of better ranked universities. Because uncertainty is a powerful force that encourages imitation (DiMaggio \& Powell, 1983), universities with lower ranking emulate the top five Romanian universities that make up the Universitaria Consortium.

There are numerous studies pointing to the gap between the expectations of employers and students (Chen, 2013; Low et al., 2013; Marshall et al., 2010). Chen (2013) points to written and oral communication, understanding the business environment and management advisory services as areas in which accounting graduates fall short in meeting employers' expectations. Though universities need to develop additional competencies, beyond the field specific ones, employers claim precisely that graduates lack soft skills. In Romania, students are provided with additional competences through transversal modules, provided by university departments, other than the ones they are enrolled in. The question whether their content meets the expectations of employers is still unanswered.

On the other hand, the connections between professional bodies from the field of accounting and audit, and the academia, established at the level of bachelor and master programs indicate the existence of a "coupling", capitalized through collaboration protocols. These stipulate the inclusion of specific mandatory subjects in the curriculum of master study programs, subsequently recognized as entry exam to the traineeship. A further capitalization form is the involvement of academics in the further training of professional accountants.

Normative isomorphism is found in the relation of universities with professional bodies and employers. The pressure exerted by the two Romanian professional bodies and ACCA is normative; the accounting study programs need to include subjects nominated in CECCAR protocols or the ACCA curricula, as well as competences claimed by employers, in order to get some reward, such as an increased attractiveness of the study programme.

According to stakeholder theory, stakeholders are "those groups without whose support the organization would cease to exist" (Freeman, 1984). When it comes to higher education, stakeholders are those groups that have a legitimate interest in education, which give them the right to intervene. More, as our study shows, the public authority (i.e. legislator, financing authority, accreditation bodies) highlights the need for a stakeholder-oriented approach. 
As shown above and summarized in Appendix C, stakeholder expectations are obviously quite divergent. As expected, according to stakeholder theory, HEIs will prioritize those stakeholders that exert more power on the organization. HEI managers are supposed to integrate stakeholder expectations in current operations and adapt study programs so as to ensure the quality of education. Universities should design their strategies starting from what stakeholders expect, since the Education Act defines quality of education not as an independent concept, but by reference to stakeholder expectations. However, universities respond to stakeholder expectations through regulations, methodologies and internal procedures on quality that are applied by all study programs. There are no specific procedures in this matter for accounting study programs. This was found by searching the websites of the five largest universities from Romania. These universities, members of the Universitaria Consortium, have Quality Management Departments, guided by a vice-rector, as well as quality control and quality assurance committees (as required by law). They prepare annual reports of institutional evaluation / self-evaluation, contribute to the preparation of specific methodologies and procedures and support teaching departments with their application. It is worth mentioning that not all internal documents regarding quality are published on the universities' websites. Therefore, our study has been limited to those documents that are publicly available.

Our study highlights the pressure that HEIs are subject to, in order to meet the requirements and expectations of stakeholders, some of them intervening directly in defining strategies, guiding policies and developing various working procedures. Through their internal regulations, HEIs are aiming at the optimization, rather than the satisfaction of stakeholder interests, which is practically impossible.

The results of our study are similar to those of Etherington and Richardson (1994). Definitely the legislator, the financing authority and the accreditation body exert a coercive pressure. Professional bodies and employers exert normative pressures, and classification and ranking bodies, as well as other universities exert mimetic pressures. Except for the legislator and the accreditation body, we find that all other stakeholders exert to a certain extent competitive pressure.

\section{Conclusions}

The paper investigated the pressures exerted by stakeholders of accounting programs provided by Romanian universities, in order to identify those elements that they converge to. Starting from stakeholder classifications existent in literature, we identified the main stakeholders of higher education institutions and accounting programs from Romania. Subsequently, we performed a review of relevant documents, in order to respond to the two questions of the research: (i) what are the requirements and expectations of each class of stakeholders? and (ii) is there any convergence between the identified expectations? 
We found that the expectations of all stakeholders have a common denominator: the quality of the education system and of the study programs. However, each class of stakeholders perceives quality in a different manner. This state of affairs generates strong pressures on HEIs, who are bound to respond to different requirements, regarding (a) the organisation, operation and definition of the activities of a HEI; (b) the design and operation of the study programs, in accordance with the requirements of the direct beneficiaries; and (c) the acknowledgement of research results. These pressures are especially exerted by the national accreditation body and the financing authority that may be considered powerful external stakeholders, that affect the legitimacy of HEIs.

We consider that the results of our study contribute to the development of knowledge from two perspectives. From a theoretical standpoint, the study provides a complex approach by combining the stakeholder and the institutional theory, in the context of the extensive environment of higher education. From a practical standpoint, by taking stock of stakeholder requirements and expectations, the study calls the attention of decision makers to stakeholder pressures and the need to adjust accounting study programs accordingly.

Though the paper provides a broad analysis of stakeholder expectations, it has several limits. Firstly, employer expectations were analysed based on studies prepared by other specific bodies or associations, and not based on an own investigation. Secondly, the identification of the convergence between different stakeholder requirements and expectations was complicated by the various perceptions of quality. Thirdly, the study was conducted only based on public documents.

As for future research directions, we consider that, after defining the general framework in which HEIs and study programs are organised and operated, we could focus on how universities are responding to the requirements and expectations of external stakeholders, as well as to the requirements of the direct beneficiaries of accounting study programs, i.e.

\section{References}

ACCA (2016) "Professional accountants - the future: drivers of change and future skills", available online at https://www.accaglobal.com/content/dam/ members-beta/docs/ea-patf-drivers-of-change-and-future-skills.pdf

Albu, N. (2013) "Exploring the recent evolution of the accounting profession in romania - an institutional approach", Accounting and Management Information System, vol. 12, no. 4: 537-552.

Amans, P., Mazars-Chapelonb, A. \& Villesèque-Dubus, F. (2015) "Budgeting in institutional complexity: The case of performing arts organizations", Management Accounting Research, vol. 27: 47-66. 
Avci, O., Ring, E. \& Mitchelli, L. (2015) "Stakeholders in U.S. higher education: an analysis through two theories of stakeholders", Bilgi Ekonomisi ve Yönetimi Dergisi, vol. X, no. 2: 45-54.

Bailey, D., Harte, G. \& Sugden, R. (2000) "Corporate disclosure and the deregulation of international investment", Accounting, Auditing \& Accountability Journal, vol. 13(2): 197-218.

Barbu, E.M. \& Baker, C.R. (2010) "An historical and neo-institutional analysis of institutions involved in international accounting convergence", Accounting and Management Information Systems, vol. 9, no 2: 218-241.

Barbu, E., Farcane, N. \& Popa, A. (2012) "Critical analysis of developments in Romanian accounting during the 20th century: a Neo-institutional approach", International Journal of Critical Accounting, vol. 4, no. 2: 175-193.

Bastedo, M.N. (2009) "Convergent Institutional Logics in Public Higher Education: State Policymaking and Governing Board Activism", The Review of Higher Education, vol. 32, no. 2: 209-234.

Bastedo, M.N. (2012) "Organizing higher education: A manifesto", in Bastedo, M.N. (Ed.), The organization of higher education: managing colleges for a new era (pp. 3-17), Baltimore: Johns Hopkins University Press.

Battilana, J., Leca, B. \& Boxenbaum, E. (2009) "How Actors Change Institutions: Towards a Theory of Institutional Entrepreneurship", The Academy of Management Annals, vol. 3, no.1: 65-107.

Beerkens, M. \& Udam, M. (2017) "Stakeholders in higher education quality assurance: richness in diversity?", Higher Education Policy, vol. 30, no. 3: 341-359.

Benneworth, P. \& Jongbloed, B.W.A (2009) "Who matters to universities? A stakeholder perspective on humanities, arts and social sciences valorisation", Higher Education, vol. 59: 567-588.

Bîrzea, C. (1997) "The dilemmas of the reform of Romanian education: shock therapy, the infusion of innovation, or cultural decommunization?", Higher Education in Europe, vol. 22, no. 3: 321-327.

Borwick, J. (2013) "Mapping the system of US higher education". HEIT Management, available online at http://www.heitmanagement.com/blog/ 2013/09/mapping-the-system-of-us-higher-education/

Brewer, P.C., Sorensen, J.E. \& Stout, D.E. (2014) "The future of accounting education: addressing the competency crisis", Strategic Finance, August: 29-37, available online at https://sfmagazine.com/wp-content/uploads/ sfarchive/2014/08/The-Future-of-Accounting-Education-Addressing-theCompetency-Crisis.pdf

Bryson, J. (2004) "What to do when stakeholders matter", Public Management Review, vol. 6, no. 1: 21-53.

Burrows, J. (1999) "Going beyond labels: A framework for profiling institutional stakeholders", Contemporary Education, vol. 70, no. 4: 5-10. 
Cai, Y. \& Mehari, Y. (2015) "The Use of Institutional Theory in Higher Education Research", in Huisman, J. \& Tight, M (eds.) Theory and Method in Higher Education Research III, Chapter: 1, Emerald Publishing.

Cai, Y. (2010) "Global isomorphism and governance reform in Chinese higher education”, Tertiary Education and Management, vol. 16, no. 3: 229-241.

Carpenter, V.L. \& Feroz, E.H. (2001) "Institutional Theory and Accounting Rule Choice: An Analysis of Four Us State Governments' Decisions to Adopt Generally Accepted Accounting Principles", Accounting, Organizations and Society, vol. 26, no. 7: 565-596.

Chapleo, C. \& Simms, C. (2010) "Stakeholder analysis in higher education: a case study of the University of Portsmouth", Perspectives: Policy and Practice in Higher Education, vol.14, no. 1: 12-20.

Chen, T.Y (2013) "A comparative study of what accounting employers in the United States and Hong Kong expect: implications for curriculum and pedagogical design", Global Perspectives on Accounting Education, vol. 10: 123-134

Covaleski, M., \& Dirsmith, M. (1986) "The budgeting process of power and politics", Accounting, Organizations and Society, vol. 11: 143-178.

Curaj A., Deca L., Hâj C.M. (2015) "Romanian Higher Education in 2009-2013. The Bologna Process and Romanian Priorities in the Search for an Active European and Global Presence", in: Curaj A., Deca L., Egron-Polak E., Salmi J. (eds) Higher Education Reforms in Romania, Cham: Springer.

Deegan, C. \& Unerman, J. (2011) Financial Accounting Theory, Berkshire: McGraw-Hill Education.

DiMaggio, P.J. (1988) "Interest and agency in institutional theory", in Zucker L.G. (Ed.), Research on Institutional Patterns: Environment and Culture, Cambridge: Ballinger Publishing Co.

DiMaggio, P.J. \& Powell, W.W. (1983) "The iron cage revisited: institutional isomorphism and collective rationality in organizational fields", American Sociological Review, vol. 48, no. 2: 147-160.

DiMaggio, P.J. \& Powell, W.W. (1991) "Introduction", in Powell W.W. \& DiMaggio P.J. (Eds.), The new institutionalism in organizational analysis (pp. 1-40). Chicago: University of Chicago Press, available online at https://woodypowell.com/wpcontent/uploads/2012/03/5_dimaggioandpowell_intro.pdf

Dobbins M. \& Knill C. (2009) "Higher Education Policies in Central and Eastern Europe: Convergence toward a Common Model?", Governance, vol. 22, no. 3: $397-430$.

Dobbins M. \& Kwiek M. (2017) "Europeanisation and globalisation in higher education in Central and Eastern Europe: 25 years of changes revisited (1990-2015)", European Educational Research Journal, vol. 16, no. 5: 519-528.

Donaldson, T. \& Preston, L. (1995) "The Stakeholder Theory of the Corporation: Concepts, Evidence, and Implications", Academy of Management Review, vol. 20: 65-91. 
Dragoescu, R.M. (2013) "Changes in Romanian higher education after 1990", Romanian Statistical Review, vol. 61(3): 28-36.

Dufour, D., Teller, P. \& Luu, Ph. (2014) "A neo-institutionalist model of the diffusion of IFRS accounting standards", Computational Economics, Springer Verlag, vol. 44, no. 1: 27-44.

Dumitru, V.F., Stanciu, A., Dumitru, M. \& Feleaga, L. (2014) "Pressure and isomorphism in business education", Amfiteatru Economic, vol. XVI, no. 37: 784-799.

Etherington L.D. \& Richardson A.J. (1994) "Institutional Pressures on University Accounting Education in Canada", Contemporary Accounting Research, vol. 10, no. 1: 141-162.

European Commission/EACEA/Eurydice (2018) The European Higher Education Area in 2018: Bologna Process Implementation Report. Luxembourg: Publications Office of the European Union.

Fligstein, N.J. (2001) "Social skill and the theory of fields", Sociological Theory, vol. 19: 105-125.

Fogarty, T.J. (1996) "The imaginary and reality of peer review in the US: Insights from institutional theory", Accounting, Organizations and Society, vol. 18: 243-267.

Freeman, R.E. (1984) Strategic Management: A stakeholder approach, Boston: Pitman.

Friedland, R. \& Alford, R.R. (1991) "Bringing society back in: Symbols, practices, and institutional contradictions", in Powell W.W. \& DiMaggio P. (Eds.), The new institutionalism in organizational analysis (pp. 232-263). Chicago: University of Chicago Press.

Frølich, N., Huisman, J., Slipersæter, S., Stensaker, B., \& Bótas, P. (2013) “A reinterpretation of institutional transformations in European higher education: strategising pluralistic organisations in multiplex environments", Higher Education, vol. 65, no. 1: 79-93.

Fujii, H. (2016) "An Institutional Theory Perspective on Accounting Evolution: Rulemakers' Belief and Empirical Evidence", in: Bensadon, D. \& Praquin, N. (eds.) IFRS in a Global World (pp. 41-56), Cham: Springer.

González-González, J.M., Arquero, J.L. \& Hassall, T. (2009) "Pressures and resistance to the introduction of skills in business administration and accounting education in Spain: A new institutional theory analysis", Journal of Vocational Education and Training, vol. 61, no. 1: 85-102.

Greenwood, R. Hinings, C.R. \& Whetten, D. (2014) "Rethinking Institutions and Organizations", Journal of Management Studies, vol. 51: 1206-1220.

Grossi, G., Dobija D. \& Strzelczyk W. (2020) "The impact of competing institutional pressures and logics on the use of performance measurement", Hybrid Universities, Public Performance \& Management Review, vol. 43(4): 818-844

Gupta, P.P., Dirsmith, M.W. \& Fogarty, T.J. (1994) "Coordination and control in a government agency: contingency and institutional theory perspectives on GAO audits", Administrative Science Quarterly, no. 39 (June): 264-284. 
Guth, K.L. (2016) "Institutional theory of organizations", in Carroll, C.E. (Ed.), Encyclopedia of corporate reputation (Vol. 1, pp. 359-361), Thousand Oaks, CA: Sage.

Gvaramadze, I. (2008) "From quality assurance to quality enhancement in the European Higher Education Area", European Journal of Education: Reseach, Development and Policy, Special Issue: The Search for Quality in the European Higher Education Area, vol. 43, no. 4: 443-455.

Hall, P.A. (2010) "Historical institutionalism in rational and sociological perspective" in Mahoney J. \& Thelen K. (Eds.), Explaining institutional change: Ambiguity, agency, and power, Cambridge: Cambridge University Press.

Hall, P., Taylor, R (1996) "Political science and the three new institutionalisms", Political Studies, vol. 44(1): 936-957.

Helliar, C. (2013) "The Global Challenge for Accounting Education, Accounting Education, vol. 22, no. 6: 510-521.

Hill, C.W. \& Jones, T.M. (1992) "Stakeholder-Agency Theory," Journal of Management Studies, vol. 29: 131-154.

IFAC (2011) "Competent and Versatile: How Professional Accountants in Business Drive Sustainable Success", available online at https://www.ifac.org /publications-resources/competent-and-versatile-how-professionalaccountants-business-drive-sustainab

Islam, M.A. (2017) "Future of accounting profession: three major changes and implications for teaching and research", IFAC Technical Report, available online at https://www.ifac.org/knowledge-gateway/business-reporting/ discussion/future-accounting-profession-three-major-changes-and

Jongbloed, B., Enders, J. \& Salerno, C. (2008) "Higher education and its communities: Interconnections, interdependencies and a research agenda", Higher Education, vol. 56, no. 3: 303-324.

Kavanagh, M.H. \& Drennan, L. (2008) "What skills and attributes does an accounting graduate need? Evidence from student perceptions and employer expectations", Accounting and Finance, vol. 48: 279-300.

Kettunen, J. (2015) "Stakeholder relationships in higher education", Tertiary Education and Management, vol. 21, no. 1: 56-65.

Koning, E. (2016) "The three institutionalism and institutional dynamics: understanding endogenous and exogenous change", Journal of Public Policy, vol.36, no.4: 639-664.

Labanauskis, R. \& Ginevičius, R. (2017) "Role of stakeholders leading to development of higher education services", Engineering Management in Production and Services, vol. 9, no. 3: 63-75.

Larrinaga-Gonzalez, C. (2007) "Sustainability reporting: insights from neoinstitutional theory", in Unerman, J., Bebbington J. \& O’Dwye B. (eds.) Sustainability accounting and accountability (pp. 169-186), Abingdon: Routledge. 
Low, M., Samkin, G. \& Liu, C. (2013) "Accounting Education and the Provision of Soft Skills: Implications of the Recent NZICA CA Academic requirement changes", e-Journal of Business Education \& Scholarship of Teaching, vol.7, no.1: 1-33.

Mainardes, E., Alves, H. \& Raposo, M. (2013) "Identifying stakeholders in a Portuguese university: a case study", Revista de Educación, no. 362: 429-457.

Mainardes, E., Alves, H. \& Raposo, M. (2012) "A model for stakeholder classification and stakeholder relationships", Management Decision, vol. 50, no. 10: 1861-1879.

Mainardes, E., Alves, H. \& Raposo, M. (2010) "An Exploratory Research on the Stakeholders of a University", Journal of Management and Strategy, vol. 1, no. 1, pp. 76-88.

Manning, K. (2013) Organizational theory in higher education. New York and London: Routledge.

Maric, I. (2013) "Stakeholder analysis of higher education institutions", Interdisciplinary Description of Complex Systems, vol. 11, no. 2: 217-226.

Marshall, P., Dombroski, R., Garner, R., \& Smith, K. (2010) "The accounting education gap", CPA Journal, vol. 80, no. 6: 6-10.

Mayper, A.G., Pavur, R.J., Merino, B.D. \& Hoops, W. (2005) "The Impact of Accounting Education on Ethical Values: An Institutional Perspective", Accounting and the Public Interest, vol. 5, no. 1: 32-55.

Melewar, T.C. \& Akel, S. (2005) "The role of corporate identity in the higher education sector", Corporate Communications: An International Journal, vol. 10, no. 1: 41-57.

Meyer, J.M. \& Rowan, B.F. (1977) "Institutionalized organizations: Formal structure as myth and ceremony", American Journal of Sociology, vol. 83, no. 2: 340-363.

Meyer, J.W., Ramirez, F.O., Frank, D.O. \& Schofer, E. (2007) "Higher Education as an Institution", in Gumport, P.J. (ed.) Sociology of Higher Education (pp. 187-221), Baltimore: The Johns Hopkins University Press.

Mihailescu I. \& Vlasceanu L. (1994) "Higher Education Structures in Romania", Higher Education in Europe, vol. 19, no. 4: 79-93.

Mitchell, R.K., Agle, B.R. \& Wood, D.J. (1997) "Towards a theory of stakeholder identification and salience: defining the principle of who and what really counts", The Academy of Management Review, vol. 22, no. 4: 853-886, available online at http://www.jstor.org/stable/pdfplus/259247.pdf

Nicolescu, L. (2002) "Reforming Higher Education in Romania", European Journal of Education, vol. 37, no. 1: 91-100.

O'Connell, B., Carnegie, G.D., Carter, A.J., de Lange, P., Hancock, P., Helliar, C.V. $\&$ Watty, K. (2015) Shaping the future of accounting in business education in Australia, CPA Australia, available online at https://www.cpaaustralia.com.au/ /media/corporate/allfiles/document/prof essional-resources/ education/shaping-the-future-final-report.pdf?la=en 
Pesqueux, Y. \& Damak-Ayadi, S. (2012) "Stakeholder theory in perspective", Corporate Governance: The International Journal of Business in Society, vol. 5, no. 2: 5-21.

Piotrowska-Piatek, A. (2016) "External stakeholders of higher education institutions in Poland - the results of empirical analysis", World Scientific News, no. 48: $10-16$.

Reale, E. \& Seeber, M. (2011) "Organisation response to institutional pressures in Higher Education: the important role of the disciplines", Higher Education, vol. 61(1): 1-22.

Saunders, V. \& Zuzel, K. (2010) "Evaluating Employability Skills: Employer and Student Perceptions", Bioscience Education, vol. 15, no.1: 1-15

Scott, W.R. \& Biag, M. (2016) "The Changing Ecology of US Higher Education: An Organization Field Perspective", in Berman, E.P. \& Paradeise, C. (eds.) The University Under Pressure (Research in the Sociology of Organizations, Volume 46, pp. 25-51), Bingley: Emerald Group Publishing Limited.

Scott, W.R. (1987) "The adolescence of institutional theory", Administrative Science Quarterly, vol. 32: 493-511.

Scott, W.R. (2008) Institutions and organizations: Ideas and interests $\left(3^{\text {rd }}\right.$ ed.), Thousand Oaks: Sage.

Scott, W.R., Ruef, M., Mendel, P. \& Caronna, C. (2000) Institutional Change and Healthcare Organizations: From Professional Dominance to Managed Care, University of Chicago Press.

Scott, W.R. (2015) "Organizational theory and higher education", Journal of Organizational Theory in Education, vol. 1, no. 1: 68-76.

Thornton, P.H., Ocasio, W. \& Lounsbury, M. (2012) The institutional logics perspective: a new approach to culture, structure and process, Oxford: Oxford University Press.

Touron, P. (2005) "The adoption of US GAAP by French firms before the creation of the International Accounting Standard Committee: an institutional explanation", Critical Perspectives on Accounting, vol. 16, no. 6: 851-873.

Tracey, P., Phillips, N. \& Jarvis, O. (2011) "Bridging institutional entrepreneurship and the creation of new organizational forms: A multilevel model", Organization Science, vol. 22: 60-80.

Tuttle, B. \& Dillard, J. (2007) "Beyond Competition: Institutional Isomorphism in U.S. Accounting Research", Accounting Horizons, vol. 21, no. 4: 387-409.

Ulewicz, R. (2017) "The role of stakeholders in quality assurance in higher education", Human Resources Management \& Ergonomics, vol. XI, no. 1: 93-107.

Watson, D. (2012) "Who Runs Our Universities?" Perspectives: Policy and Practice in Higher Education, vol. 16, no.2: 41-45.

Zhang, G., Boyce, G. \& Ahmed, K. (2014) "Institutional changes in university accounting education in post-revolutionary China: From political orientation to internationalization", Critical Perspectives on Accounting, vol. 25, no. 8: 819-843. 
Zietsma, C. \& Lawrence, T.B. (2010) "Institutional work in the transformation of an organizational field: the interplay of boundary work and practice work", Administrative Science Quarterly, vol. 55: 189-221.

Zimmerman, A.B., Fogarty, T.J. \& Jonas, G.A. (2017) "Is accounting an applied discipline? An institutional theory assessment of the value of faculty accounting-related work experience in the academic labor market", Journal of Accounting Education, vol. 41: 33-47.

*** ESG (2015), Standards and Guidelines for Quality Assurance in the European Higher Education Area, Brussels, Belgium.

*** Government Decision no. 789/2011 on the approval of the Evaluation methodology for university classification and study program ranking, Official Gazette of Romania no. 569 / 2011

*** Law no. 88/1993 on the accreditation of Higher Education Institutions and the acceptance of degrees

*** Law no. 84 / 1995, Education Act, Official Gazette of Romania no. 67 / 1995

*** Law no. 128 / 1997 on the statute of academics, Official Gazette of Romania no. $158 / 1997$

*** Law no. 1 / 2011 The National Education Act, Official Gazette of Romania no. 18 / 2011, with all subsequent amendments and completions

*** Law no. 162 / 2017 on the statutory audit of the annual financial statements and annual consolidated financial statements, and on the amendment of some regulations, Official Gazette of Romania no. 548 / 2017

*** Methodology for external evaluation, the standards, reference standards and the list of performance indicators of The Romanian Agency for Quality Assurance in Higher Education, approved by the ARACIS Council on 29.06.2017

*** Ordinance no. 75/2005 on quality assurance, updated June 2021, available online at https://www.aracis.ro/wp-content/uploads/2021/06/ordonanta-deurgenta-nr-75-2005-privind-asigurarea-calitatii-educatiei-actualizata2021pdf.pdf

*** Ordinance no. 65/1994 on the regulation of accounting expertise and chartered accountants (reprinted), Official Gazette of Romania no. 13 / 2008 with subsequent amendments

*** The Order of the Ministry of National Education no. 3047 / 2018 on the approval of the Allocation methodology of budgetary funds for the base funding and the supplementary funding of public higher education institutions from Romania, Official Gazette of Romania no. 127 / 2018 
External pressures on accounting study programs:

An institutional approach of stakeholder expectations

Appendix A. Institutional changes of Romanian HE between 1990-2010

\begin{tabular}{|c|c|}
\hline Period & Institutional change \\
\hline 1990-1994 & $\begin{array}{l}\text { - granting de facto institutional autonomy to universities; } \\
\text { - } \text { re-establishing freedom in teaching, learning and research; } \\
\text { - changes in curriculum, textbooks, teaching methods; } \\
\text { - a large number of public and private universities; public universities } \\
\text { don't have a legal base; } \\
\text { - a large number of study programs, academics and students; } \\
\text { - } \text { small steps in management reform; } \\
\text { - enactment of new legislation: Law on the Accreditation of Higher } \\
\text { Education Institutions and the Recognition of Diplomas (Law no. } \\
\text { 88/1993). }\end{array}$ \\
\hline $\begin{array}{l}1995 \text { - } \\
1997\end{array}$ & 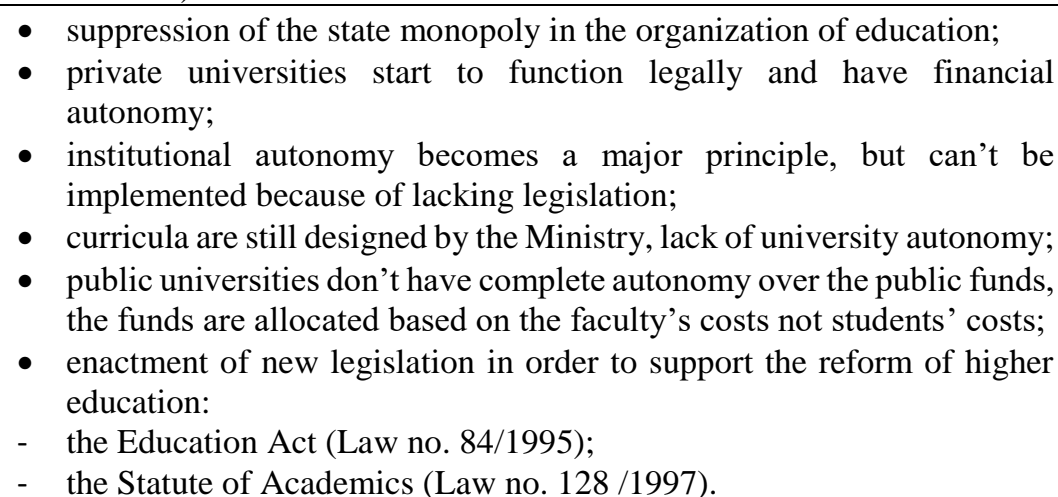 \\
\hline 1998-1999 & 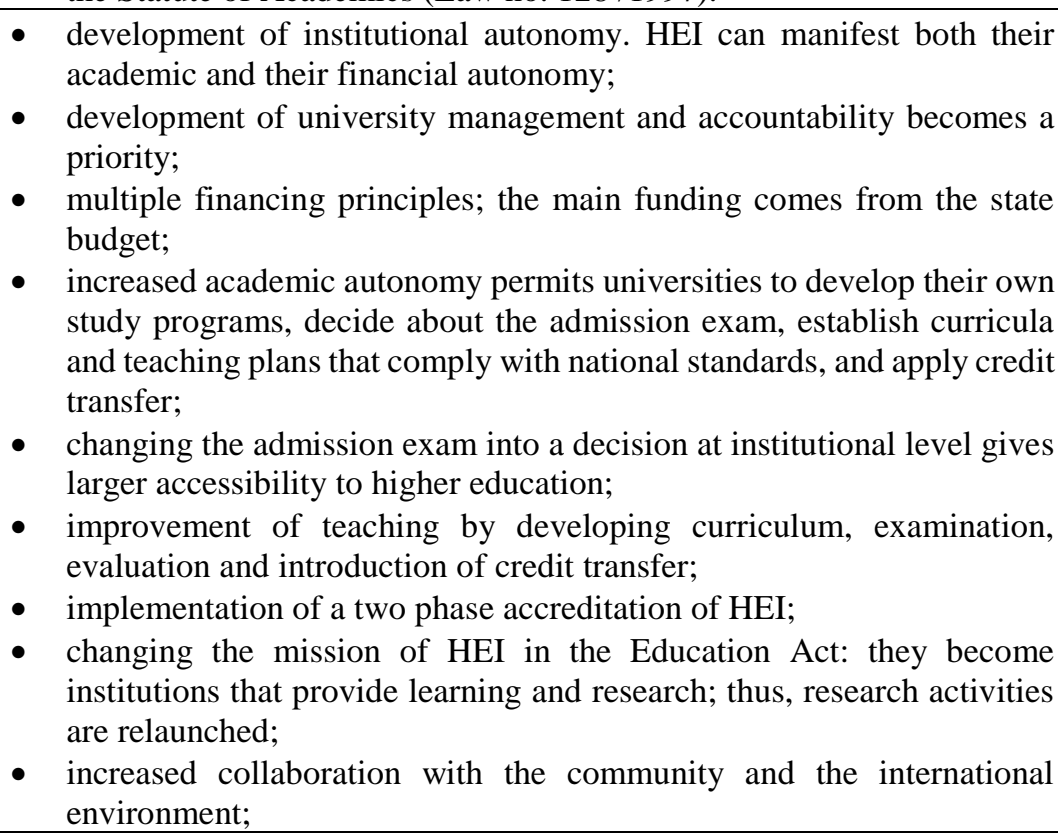 \\
\hline
\end{tabular}

Vol. 20, No. 4 


\begin{tabular}{|c|c|}
\hline Period & Institutional change \\
\hline & $\begin{array}{l}\text { - change of legislation: the Education Act is updated; many other } \\
\text { regulations are promoted to support and speed up the reform; } \\
\text { establishment of several specialized institutional bodies, either within } \\
\text { or independent of the Ministry of Education, with the objective to advise } \\
\text { and assist the Ministry in the implementation of the reform; } \\
\text { signing of the Bologna Declaration in 1999, aiming to align higher } \\
\text { education with the emerging pan-European system. }\end{array}$ \\
\hline $2000-2006$ & $\begin{array}{l}\text { - implementation of a new public financing mechanism for HEI, with two } \\
\text { components: main part of the public funding is based on block grants, } \\
\text { and the second part is a differential financing based on a qualitative } \\
\text { component; } \\
\text { - specific legislation is adopted in order to move towards the } \\
\text { implementation of the Bologna process; } \\
\text { - higher education study programmes are organized into three cycles: } \\
\text { bachelor, master and doctoral studies; } \\
\text { - ECTS becomes mandatory for each university; } \\
\text { - the law on quality assurance in education, inspired by Bologna, is } \\
\text { enacted; } \\
\text { - an independent public institution is established, with competences in } \\
\text { accreditation, quality review and quality assurance of HEI: Romanian } \\
\text { Agency for Quality Assurance in Higher Education (ARACIS). }\end{array}$ \\
\hline $2007-2010$ & $\begin{array}{l}\text { - increased focus on institutional performance both by the Ministry of } \\
\text { Education and by HEI; } \\
\text { steps towards implementation of the principles of the Bologna process } \\
\text { taken by individual universities; } \\
\text { an analysis of the state of Romanian research and higher education } \\
\text { within the European framework; } \\
\text { development of a new reform in the strategy in HE agreed with the key } \\
\text { stakeholders. The main issues identified to be reformed are curricula, } \\
\text { the management of HEIs, full university autonomy, classification of } \\
\text { universities by their mission statements and achievements and ranking } \\
\text { of study programs, introducing student charter, improving equity in } \\
\text { higher education and lifelong learning programs, as a basis for } \\
\text { increasing participation rates in higher education. }\end{array}$ \\
\hline
\end{tabular}


External pressures on accounting study programs:

An institutional approach of stakeholder expectations

\section{Appendix B. Sources used for data collection}

\begin{tabular}{|c|c|}
\hline Stakeholder & Sources used \\
\hline Legislator & National Education Act no. 1/2011 \\
\hline $\begin{array}{l}\text { Financing } \\
\text { authority }\end{array}$ & $\begin{array}{l}\text { National Education Act no. 1/2011 } \\
\text { The Order of the Ministry of National Education no. } 3047 \text { / } 2018 \text { on the } \\
\text { approval of the Allocation methodology of budgetary funds for the base } \\
\text { funding and the supplementary funding of public higher education } \\
\text { institutions from Romania, Official Gazette of Romania no. } 127 \text { / } 2018\end{array}$ \\
\hline $\begin{array}{l}\text { Accreditation } \\
\text { bodies }\end{array}$ & $\begin{array}{l}\text { Ordinance no. } 75 / 2005 \text { on quality assurance, updated June 2021, } \\
\text { available online at https://www.aracis.ro/wp-content/uploads/2021/06/ } \\
\text { ordonanta-de-urgenta-nr-75-2005-privind-asigurarea-calitatii-educatiei- } \\
\text { actualizata-2021pdf.pdf } \\
\text { Methodology for external evaluation, the standards, reference standards } \\
\text { and the list of performance indicators of The Romanian Agency for } \\
\text { Quality Assurance in Higher Education, updated 2020, available online } \\
\text { at https://www.aracis.ro/wp-content/uploads/2020/07/METODO1-3.pdf }\end{array}$ \\
\hline $\begin{array}{l}\text { Classification } \\
\text { /ranking } \\
\text { agencies }\end{array}$ & $\begin{array}{l}\text { Government Decision no. } 789 / 2011 \text { on the approval of the Evaluation } \\
\text { methodology for university classification and study program ranking, } \\
\text { Official Gazette of Romania no. } 569 / 2011\end{array}$ \\
\hline $\begin{array}{l}\text { Other } \\
\text { universities }\end{array}$ & Statute of the Universitaria Consortium \\
\hline Employers & $\begin{array}{l}\text { ACCA (2016) "Professional accountants - the future: drivers of change } \\
\text { and future skills", available online at https://www.accaglobal.com/ } \\
\text { content/dam/members-beta/docs/ea-patf-drivers-of-change-and-future- } \\
\text { skills.pdf } \\
\text { IFAC (2011) "Competent and Versatile: How Professional Accountants } \\
\text { in Business Drive Sustainable Success", available online at } \\
\text { https://www.ifac.org/publications-resources/competent-and-versatile- } \\
\text { how-professional-accountants-business-drive-sustainab }\end{array}$ \\
\hline $\begin{array}{l}\text { Professional } \\
\text { bodies }\end{array}$ & $\begin{array}{l}\text { Ordinance no. 65/1994 on the regulation of accounting expertise and } \\
\text { chartered accountants (reprinted), Official Gazette of Romania no. } 13 \text { / } \\
2008 \text { with subsequent amendments } \\
\text { Law no. } 162 / 2017 \text { on the statutory audit of individual financial statements } \\
\text { and consolidated financial statements, and on the amendment of several } \\
\text { regulations }\end{array}$ \\
\hline
\end{tabular}




\begin{tabular}{|c|c|c|c|c|c|}
\hline \multicolumn{6}{|c|}{ Appendix C. Main findings } \\
\hline Stakeholder & Role & $\begin{array}{c}\text { Pressures: } \\
\text { (Requirements } \\
\text { \& expectations) }\end{array}$ & $\begin{array}{c}\text { Common } \\
\text { denominator } \\
\text { Quality }\end{array}$ & $\begin{array}{c}\text { Scope } \\
\text { of the } \\
\text { impact }\end{array}$ & $\begin{array}{c}\text { Isomorphic } \\
\text { pressure }\end{array}$ \\
\hline $\begin{array}{l}\text { Legislator } \\
\text { (Ministry of } \\
\text { Education) }\end{array}$ & $\begin{array}{l}\text { Issues the } \\
\text { National } \\
\text { Education } \\
\text { Act. } \\
\text { Establishes a } \\
\text { clear } \\
\text { connection } \\
\text { between } \\
\text { quality and } \\
\text { the } \\
\text { expectations } \\
\text { of } \\
\text { beneficiaries. }\end{array}$ & $\begin{array}{l}\text { Designing the } \\
\text { organizational } \\
\text { context under the } \\
\text { legal provisions; } \\
\text { Defining the } \\
\text { inputs, taking into } \\
\text { account the } \\
\text { expectations of all } \\
\text { stakeholders; }\end{array}$ & $\begin{array}{l}\text { Aims at } \\
\text { quality, not } \\
\text { defined per } \\
\text { se but by } \\
\text { reference to } \\
\text { the } \\
\text { expectations } \\
\text { of third } \\
\text { parties, or to } \\
\text { external } \\
\text { standards. }\end{array}$ & institutional & coercive \\
\hline $\begin{array}{l}\text { Financing } \\
\text { authority }\end{array}$ & $\begin{array}{l}\text { Establishes } \\
\text { funding } \\
\text { criteria for } \\
\text { universities. }\end{array}$ & $\begin{array}{l}\text { Attracting a large } \\
\text { number of } \\
\text { students in order } \\
\text { to ensure the basic } \\
\text { funding (on the } \\
\text { average cost per } \\
\text { equivalent } \\
\text { student); } \\
\text { Meeting the } \\
\text { criteria for } \\
\text { ensuring the } \\
\text { supplementary } \\
\text { funding (based on } \\
\text { four criteria; the } \\
\text { scientific research } \\
\text { has the largest } \\
\text { share); } \\
\text { Developing } \\
\text { specific projects } \\
\text { for institutional } \\
\text { development; } \\
\text { Promoting new } \\
\text { study programs, } \\
\text { increasing the } \\
\text { institutional } \\
\text { capacity; } \\
\text { Developing the } \\
\text { research } \\
\text { infrastructure; } \\
\text { Maintaining the } \\
\text { relationship with } \\
\text { the local and/or } \\
\text { regional } \\
\text { community; }\end{array}$ & $\begin{array}{l}\text { Quality is } \\
\text { assessed in } \\
\text { terms of } \\
\text { measures } \\
\text { used for } \\
\text { funding. }\end{array}$ & institutional & coercive \\
\hline
\end{tabular}


External pressures on accounting study programs:

An institutional approach of stakeholder expectations

\begin{tabular}{|c|c|c|c|c|c|}
\hline Stakeholder & Role & $\begin{array}{c}\text { Pressures: } \\
\text { (Requirements } \\
\text { \& expectations) }\end{array}$ & $\begin{array}{c}\text { Common } \\
\text { denominator } \\
\text { Quality }\end{array}$ & $\begin{array}{l}\text { Scope } \\
\text { of the } \\
\text { impact }\end{array}$ & $\begin{array}{l}\text { Isomorphic } \\
\text { pressure }\end{array}$ \\
\hline & & $\begin{array}{l}\text { Assuring the } \\
\text { sustainability and } \\
\text { competitive } \\
\text { development of } \\
\text { society, which } \\
\text { gives those fields } \\
\text { priority to } \\
\text { funding; }\end{array}$ & & & \\
\hline $\begin{array}{l}\text { Accreditation } \\
\text { bodies }\end{array}$ & $\begin{array}{l}\text { Issues the } \\
\text { methodology } \\
\text { and guides } \\
\text { for external } \\
\text { evaluation. } \\
\text { Performs the } \\
\text { evaluation of } \\
\text { quality in HE } \\
\text { Harmonizes } \\
\text { the national } \\
\text { accreditation } \\
\text { methodology } \\
\text { with the } \\
\text { European } \\
\text { one }\end{array}$ & $\begin{array}{l}\text { Ensuring physical } \\
\text { resources, } \\
\text { financial resources } \\
\text { and human } \\
\text { resources to meet } \\
\text { the institutional } \\
\text { capacity criteria; } \\
\text { Meeting the } \\
\text { criteria for } \\
\text { educational } \\
\text { effectiveness } \\
\text { (criteria that } \\
\text { include both } \\
\text { teaching and } \\
\text { research activity); } \\
\text { Implementing } \\
\text { strategies, } \\
\text { structures, } \\
\text { techniques and } \\
\text { operations through } \\
\text { which HEI show } \\
\text { that they evaluate } \\
\text { their own } \\
\text { performance in } \\
\text { assuring and } \\
\text { enhancing the } \\
\text { quality of } \\
\text { education }\end{array}$ & $\begin{array}{l}\text { Quality is } \\
\text { assessed in } \\
\text { terms of } \\
\text { fulfilling the } \\
\text { accreditation } \\
\text { criteria. }\end{array}$ & mixed & coercive \\
\hline $\begin{array}{l}\text { Classification } \\
\text { / ranking } \\
\text { agencies }\end{array}$ & $\begin{array}{l}\text { Rank HEIs } \\
\text { and study } \\
\text { programs. }\end{array}$ & $\begin{array}{l}\text { Meeting the } \\
\text { criteria for HEIs } \\
\text { classification / } \\
\text { ranking; } \\
\text { Meeting the } \\
\text { criteria used to } \\
\text { rank accounting } \\
\text { study programs; }\end{array}$ & $\begin{array}{l}\text { Quality is } \\
\text { assessed } \\
\text { based on } \\
\text { various } \\
\text { classification } \\
\text { / ranking } \\
\text { criteria. }\end{array}$ & mixed & $\begin{array}{l}\text { mimetic \& } \\
\text { competitive }\end{array}$ \\
\hline $\begin{array}{l}\text { Other } \\
\text { universities }\end{array}$ & $\begin{array}{l}\text { Compete to } \\
\text { attract } \\
\text { students. } \\
\text { Collaborate } \\
\text { to improve }\end{array}$ & $\begin{array}{l}\text { Improving the } \\
\text { educational offer } \\
\text { in order to attract } \\
\text { more students; }\end{array}$ & $\begin{array}{l}\text { Don't issue } \\
\text { quality } \\
\text { requirements } \\
\text { as other } \\
\text { stakeholders. }\end{array}$ & mixed & $\begin{array}{l}\text { mimetic \& } \\
\text { competitive }\end{array}$ \\
\hline
\end{tabular}

Vol. 20, No. 4 
Accounting and Management Information Systems

\begin{tabular}{|c|c|c|c|c|c|}
\hline Stakeholder & Role & $\begin{array}{c}\text { Pressures: } \\
\text { (Requirements } \\
\text { \& expectations) }\end{array}$ & $\begin{array}{c}\text { Common } \\
\text { denominator } \\
\text { Quality }\end{array}$ & $\begin{array}{l}\text { Scope } \\
\text { of the } \\
\text { impact }\end{array}$ & $\begin{array}{c}\text { Isomorphic } \\
\text { pressure }\end{array}$ \\
\hline & $\begin{array}{l}\text { the } \\
\text { regulation } \\
\text { framework. }\end{array}$ & $\begin{array}{l}\text { Adjusting and } \\
\text { correlating the } \\
\text { study programs; } \\
\text { Strengthening } \\
\text { partnerships in } \\
\text { order to improve } \\
\text { the quality of } \\
\text { research and } \\
\text { teaching; }\end{array}$ & & & \\
\hline Employers & $\begin{array}{l}\text { Define the } \\
\text { skills and } \\
\text { competencies } \\
\text { that students } \\
\text { need to } \\
\text { acquire. }\end{array}$ & $\begin{array}{l}\text { Adjusting the } \\
\text { study programs } \\
\text { according to the } \\
\text { future role of } \\
\text { accountants; }\end{array}$ & $\begin{array}{l}\text { Quality is } \\
\text { assessed } \\
\text { through the } \\
\text { competencies } \\
\text { and skills of } \\
\text { the } \\
\text { graduates. }\end{array}$ & $\begin{array}{l}\text { study } \\
\text { program }\end{array}$ & normative \\
\hline $\begin{array}{l}\text { Professional } \\
\text { bodies }\end{array}$ & $\begin{array}{l}\text { Ensure that } \\
\text { the } \\
\text { accounting } \\
\text { profession } \\
\text { serves the } \\
\text { public } \\
\text { interest. }\end{array}$ & $\begin{array}{l}\text { Adapting the } \\
\text { content of the } \\
\text { accounting master } \\
\text { programs; } \\
\text { Adjusting the } \\
\text { curricula for the } \\
\text { accreditation of } \\
\text { study programs; } \\
\text { Getting closer to } \\
\text { the needs of the } \\
\text { business } \\
\text { environment. } \\
\text { Ensuring the } \\
\text { acquisition of } \\
\text { technical } \\
\text { knowledge and } \\
\text { competences, } \\
\text { developing a } \\
\text { holistic approach } \\
\text { in terms of } \\
\text { competencies. }\end{array}$ & $\begin{array}{l}\text { Quality is } \\
\text { assessed } \\
\text { through } \\
\text { relevance of } \\
\text { students' } \\
\text { training in } \\
\text { relation to } \\
\text { the } \\
\text { requirements } \\
\text { of the } \\
\text { profession. }\end{array}$ & $\begin{array}{l}\text { study } \\
\text { program }\end{array}$ & normative \\
\hline
\end{tabular}

